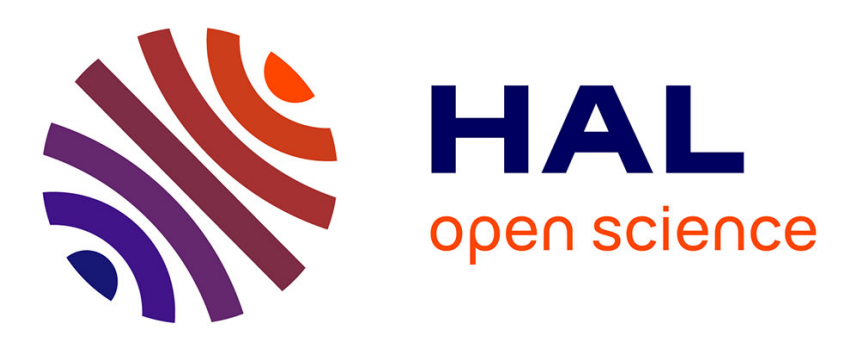

\title{
Evolution of the Radular Apparatus in Conoidea (Gastropoda: Neogastropoda) as Inferred from a Molecular Phylogeny
}

\author{
Yuri I Kantor, Nicolas Puillandre
}

\section{- To cite this version:}

Yuri I Kantor, Nicolas Puillandre. Evolution of the Radular Apparatus in Conoidea (Gastropoda: Neogastropoda) as Inferred from a Molecular Phylogeny. Malacologia, 2012, 55 (1), pp.55-90. 10.4002/040.055.0105 . hal-02458196

\author{
HAL Id: hal-02458196 \\ https://hal.science/hal-02458196
}

Submitted on 28 Jan 2020

HAL is a multi-disciplinary open access archive for the deposit and dissemination of scientific research documents, whether they are published or not. The documents may come from teaching and research institutions in France or abroad, or from public or private research centers.
L'archive ouverte pluridisciplinaire HAL, est destinée au dépôt et à la diffusion de documents scientifiques de niveau recherche, publiés ou non, émanant des établissements d'enseignement et de recherche français ou étrangers, des laboratoires publics ou privés. 


\title{
EVOLUTION OF THE RADULAR APPARATUS
}

IN CONOIDEA (GASTROPODA: NEOGASTROPODA) AS INFERRED FROM A MOLECULAR PHYLOGENY

\section{Kantor Yu. I.*1, Puillandre N. ${ }^{2}$}

\author{
${ }^{1}$ A.N. Severtsov Institute of Ecology and Evolution, Russian Academy of Sciences, \\ Leninski Prosp. 33, Moscow 119071, Russia; \\ 2 UMR 7138, Muséum National d'Histoire Naturelle, Departement Systematique et \\ Evolution, 55, Rue Buffon, 75231 Paris, France
}

Running title: Evolution of radula in Conoidea

\begin{abstract}
The radular anatomy and evolution of the radular apparatus in predatory marine gastropods, superfamily Conoidea, is reconstructed on the basis of a molecular phylogeny, based on three mitochondrial genes (COI, 12S and 16S) for 101 species. A unique feeding mechanism involving use of individual marginal radular teeth at the proboscis tip for stabbing and envenomation of prey at the proboscis tip appeared at the earliest stages of evolution of the group. The initial major evolutionary event in Conoidea was the divergence to two main branches. One is characterized by mostly hypodermic marginal teeth and absence of an odontophore, while the other possesses a radula with primarily duplex marginal teeth, a strong subradular membrane and retains a fully functional odontophore. The radular types that have previously been considered most ancestral, "prototypic" for the group (flat marginal teeth; multicuspid lateral teeth of Drilliidae; solid recurved teeth of Pseudomelatoma and Duplicaria), were found to be derived conditions. Solid recurved teeth appeared twice, independently, in Conoidea - in Pseudomelatomidae and Terebridae. The Terebridae, the sister group of Turridae, are characterized by very high radular variability, and the transformation of the marginal radular teeth within this single clade repeats the evolution of the radular apparatus across the entire Conoidea.
\end{abstract}

Conoidea, Conus, radula, molecular phylogeny, evolution, feeding mechanisms, toxins, morphological convergence, character mapping

* Corresponding author: kantor@malaco-sevin.msk.ru 
Gastropods of the superfamily Conoidea (= Toxoglossa) constitute a hyperdiverse group of predatory marine snails that includes in particular the famous genus Conus. Conoideans are notable for the possession of a large venom gland (Figs. 1-4, vg), together with a highly modified radula.

An unusual peculiarity of Conoidean foregut anatomy is that the buccal mass with the radular sac is situated at the proboscis base (Fig. 1 - bm, rsod) and the radula cannot be protruded through the mouth and used for grabbing and rasping the prey.

The most outstanding character of Conoidea is the unique mechanism of envenomation of the prey. Some conoideans were long known to use individual teeth at the proboscis tip for stabbing and injecting neurotoxins into prey (eg. Kohn, 1956). A marginal tooth is detached from the subradular membrane (when present), transferred to the proboscis tip (Figs. 2, 4), held by sphincter(s) in the buccal tube (Figs. 2, 4 - bts) and used for stabbing and envenomating the prey. Use of marginal teeth at the proboscis tip was observed directly and studied in detail in various species of Conus that possess elongate, barbed, harpoon-like, hollow marginal teeth (Kohn, 1990; Olivera et al., 1990; Kohn, Nishi \& Pernet, 1999), through which the venom is injected into the prey. The prey is swallowed whole, sometimes being similar in size to the predator itself (eg. Kantor, 2007). In these cases the radular apparatus underwent profound transformation and the odontophore completely disappeared. Another important character is that the anterior part of the radular diverticulum, which is homologous to the sublingual pouch of other gastropods, is transformed into a caecum ("short-arm of the radular sac"), where fully formed marginal teeth are stored prior to their use on the proboscis tip (Taylor et al., 1993).

Conversely, in many conoideans the radular apparatus includes a radula with a well developed subradular membrane and a fully functional odontophore with muscles, thus suggesting that the radula still has some (although maybe limited) function as a complete organ. As in conoideans with hypodermic teeth, the radula and odontophore are situated at the proboscis base and normally cannot be protruded through the mouth (Fig. 1). In conoideans with non-hypodermic marginal teeth (and a functional odontophore) the separate tooth was very often (in most preserved specimens examined) found held at the proboscis tip (Figs. 1-2). Teeth were first recorded in serial histological sections of probosces in several species of Aforia (Cochlespiridae) (Sysoev \& Kantor 1987), Drilliidae (Sysoev \& Kantor 1989), and in three additional families, here 
referred to as Turridae, Clavatulidae and Pseudomelatomidae (Kantor \& Taylor, 1991). The base of the tooth was held by special sphincter(s) and/or an epithelial pad of the buccal tube. Thus the presence of marginal teeth detached from the radular membrane and of different morphologies, from solid duplex to specialized hypodermic, used one by one at the proboscis tip for stabbing the prey can be inferred from anatomical characters (presence of the sphincters in the buccal tube).

Peculiarities of the feeding mechanisms have been discussed for different groups of Conoidea (eg. Taylor et. al., 1993; Kantor et al., 1997; Kantor \& Taylor, 2002) and several feeding mechanisms have been suggested. Based on the foregut anatomy, the use of the teeth at the proboscis tip was found improbable in only two groups of radulate Conoidea that possess the proboscis - Strictispiridae, and the clade formed by the genera Pseudomelatoma, Hormospira and Tiariturris, previously recognized as a separate (sub)family Pseudomelatomidae (Kantor, 1988; Kantor \& Taylor, 1991, 1994). In all others the marginal teeth are used at the proboscis tip.

Despite the fact that the Conoidea are one of the most well-known groups of Neogastropoda from the point of view of anatomy and lately molecular phylogeny, data on their feeding and diet are still very limited. With the exception of Conus information on feeding is available for fewer than 50 species and involved much less direct observation (eg. Heralde et al., 2010). Most of the conoideans (other than Conus) feed on sedentary and errant polychaetes, although feeding on other worms (sipunculans and nemerteans) and even molluscs has been recorded (Miller, 1989, 1990). This information is derived mainly from gut content analysis.

Radular anatomy of the Conoidea is highly variable both in terms of the number of teeth in a transverse row and in the shape of the teeth. For a long time, radula morphology together with shell characters constituted the basis of the higher classification of the group (e.g. Powell, 1942, 1966; McLean, 1971). Since about 1990 anatomical investigations of conoideans have revealed great variability in foregut anatomy, and characters defined in these studies have been used to unravel phylogenetic relationships (Taylor, 1990; Taylor et al., 1993; Kantor, Medinskaya \& Taylor, 1997). Various hypotheses have been proposed concerning the evolutionary transformations in radular morphology of Conoidea (Shimek \& Kohn, 1981; Kantor \& Taylor, 2000; Kantor, 2006). However, one of the reasons for the lack of a clear understanding of major radular transformations is that radula evolution was inferred from phylogenetic hypotheses themselves based partially on radular morphology (eg. 
Taylor et al., 1993). As a consequence many parallel evolutionary transformations cannot be traced.

The rapid development of molecular phylogenetics provided new insight and revolutionary changes in our understanding of conoidean evolution. DNA sequences were first used to infer phylogenetic relationships within genera or subfamilies (e.g. Espiritu et al., 2001; Duda \& Kohn, 2005; Heralde et al., 2007; Holford et al., 2009) and then among most of the families and subfamilies (as erected by Powell, 1942, 1966; McLean, 1971; Taylor et al., 1993) of the Conoidea (Puillandre et al. 2008). An updated molecular phylogeny based on three mitochondrial genes (COI, 12S and 16S) and including representatives of 103 genera was recently proposed (Puillandre et al., 2011). The single recognized taxon missing from the analysis was the (sub)family Strictispiridae McLean, 1971. Most of the clades inferred have robust support that allowed the status of the different families and subfamilies previously proposed to be clarified and lead to a new classification of the group into 15 families (Bouchet et al., 2011).

The molecular framework provides an opportunity to reconstruct the transformation of the morphological characters and to test previously proposed hypotheses. This approach has demonstrated the independent loss of the venom gland in two independent lineages of Terebridae (Holford et al., 2009), but is still not widely used in Conoidea. Here we attempt a reconstruction of the major morphological transformations of the radular apparatus in Conoidea based on the molecular phylogeny. For the first time evolution of the radular apparatus is discussed based on a framework reconstructed using characters completely independent of anatomy, that is DNA sequences. Understanding the transformations of the radular apparatus is important not only for understanding the evolution of the group in general, but also because it may provide new insight into the factors leading to hyperdiversification of the group that lead to the appearance of probably the most diverse marine mollusc taxon in terms of species richness. Furthermore, clarifying the evolution of the group, and in particular the evolution of characters linked to the venom apparatus, should be of great value in the discovery of new venom compounds with pharmacological applications (Olivera 2006, Puillandre \& Holford 2010). 
Material and methods

\section{Radula preparation}

Of the 102 ingroup species in the molecular analysis (Puillandre et al. 2011), the radula of 51 species was examined (in most cases using the same specimens as used for the molecular analysis), 10 species were radula-less, and for 13 species published data were used (Table 2). In most cases unavailability of the radula was explained by destruction of the body during DNA extraction (usually for very small specimens). For six species radular characters were examined using congeners (usually those whose position within the genus was confirmed by other molecular data). These species are marked by an asterisk on the molecular trees. The complete range of variability of the radula in Conoidea is not, however, covered by the species in our tree (only a single species of each genus was used in the analysis). Although some species with important or unique radular morphology are not included in the current analysis, from separate molecular analyses we know their phylogenetic position and therefore these species are sometimes mentioned in the discussion.

The radulae were always cleaned with diluted bleach (1 part of commercially available bleach to 3-4 parts of distilled water). Cleaning radulae in bleach does not damage radular teeth or the subradular membrane if used in the correct concentration and if the radulae are not exposed to bleach for a long time. Furthermore, soft tissues are diluted in bleach rapidly (usually within a few minutes), allowing continuous observation under the microscope that reveals many important features that otherwise can easily be overlooked, eg. folding of the radular membrane, attachment of radular teeth to the membrane, presence of a ligament, etc.

The tiny radulae were cleaned in a drop of water placed on a cover-slip. The bleach was added either with a syringe or a minute plastic pipette. After dissolving the soft tissues the radula or separate radular teeth were transferred with a needle or single hair into a drop of clean water on the same cover-slip. This minimizes the chance of losing the small radulae. Two changes of water were usually enough to rinse the radula. After rinsing, the radula was partially pulled out of the drop so that the extruded part adheres to the glass by surface tension. This permits the radula membrane to be more easily unfolded with a single hair, and allows individual teeth to be placed in the desired position prior to drying. The radula was then completely pulled out of the water drop and allowed to dry. The cover-slip was then mounted on the stub. Although simple, this 
method provides excellent results, allowing manipulating objects smaller then $100 \mu \mathrm{m}$ in length.

Acronyms for depositories of voucher specimens

INVEMAR - Instituto de Investigaciones Marinas y Costeros, Colombia

MNHN -- Muséum National d'Histoire Naturelle Paris, France

MNZ - Museum of New Zealand Te Papa Tongareva, Wellington, New Zealand

NHMUK - Natural History Museum, London, UK

USNM - National Museum of Natural History, Smithsonian Institution, Washington DC, USA

\section{Tree mapping}

Nine radular morphology characters coded as 31 character states (Table 1) were used for reconstruction of the radular transformation. Characters were mapped on the tree of Puillandre et al. (2011) using Mesquite Version 2.74 (Maddison \& Maddison, 2007-2010), using the option "tracing character history" and the parsimony ancestral reconstruction method. Most of the characters were treated as unordered. For the characters describing central and lateral teeth (characters \# 1 \& 2 in Table 1) the stepmatrix model was tried in addition to the unordered; it allows interdicting some of the transformation sequences, in our case from absent to present, that is interdicting reappearance of central and lateral teeth after they had been lost.

The familiar classification accepted here is that of Bouchet et al. (2011). For convenience, in addition to the families recognized by Bouchet et al. (2011) we refer to major clades A and B (without attributing any taxonomic status to them) that are different in many aspects of anatomy and radular morphology.

Results

Although the radulae of Conoidea have been described in many publications, the thorough use of scanning electron microscopy revealed many previously overlooked characters and allowed new interpretations of structures already described. Therefore we provide here a much updated overview of the radular characters. The evolution of each of the nine characters analysed is described.

Character 1. Central tooth of the radula (Figs. 5 and 6). 
A central tooth is present in all outgroups. It is absent in clade $A$ and present in some groups of clade $\mathrm{B}$. The morphology of the central tooth is rather variable in gastropods. Two major types are found in the outgroups, both multicuspid. Describing in detail the morphology of the teeth of groups other than Conoidea (eg. Bandel, 1984) is outside the scope of the current paper. In Conoidea the situation with the central tooth is very confusing. In some species the central tooth appears as a well-defined structure. Two major types of such teeth can be identified: narrow unicuspid (shield-like with a small cusp and sometimes with additional serrations) (Figs. 7-9, 12-13); and broad unicuspid, with a large curved cusp and well defined lateral flaps (Fig. 14).

Conversely, in a number of Conoidea from clade B there are vestigial rather indistinct structure(s) occupying the middle portion of the subradular membrane (Fig. 29, 31 - marked with arrows). In some cases they can be hardly seen without staining the radular membrane or even under SEM. These structures may be either a much reduced broad central tooth with lateral flaps with or even without a central cusp, or alternatively three teeth - vestigial central and vestigial laterals (see below) partially or completely fused (Fig. 17-18). Vestigial structures were found in some Pseudomelatomidae, Clavatulidae and Turridae (Iotyrris Medinskaya \& Sysoev, 2001).

Narrow unicuspid central teeth are found in most Drilliidae and some Turridae (in our dataset exemplified by species of Xenuroturris Iredale, 1929 and Turridrupa Hedley, 1922 - Figs. 34-35, as well as Gemmula and Turris). A broad well defined central tooth was recorded in three clades - in some Pseudomelatomidae (Pseudomelatoma, Hormospira Berry, 1958 and Tiariturris Berry, 1958 - Fig. 14), Cochlespiridae (Fig. 40), and Gemmuloborsonia Shuto, 1989 (not currently attributed to any family - Fig. 32). In these genera the posterior edge of the tooth, bearing the cusp, is well elevated over the membrane.

Four analyses were performed. In the first, the inconspicuous central teeth, when recognized, were considered as unicuspid narrow (lateral flaps were considered as vestigial plate-like lateral teeth), and character states were unordered (Fig. 5). The tree was 13 steps long and suggested that the plesiomorphic condition of the character in clade $B$ is the absence of the central tooth and the central teeth originated independently in 8 clades. Since central teeth are present in the outgroups this can be considered a reversion. However, the presence of numerous reversions within clade $B$ seems rather unlikely.

Therefore the second analysis was performed with reversions interdicted (stepmatrix parsimony model) (Fig. 6). The tree was 18 steps long (5 steps longer) and 
the analysis did not allow reconstruction of the single most parsimonious state in Clade $B$, since a multicuspid tooth (characteristic for Neogastropoda), a narrow unicupsid tooth and a broad unicuspid tooth are equally parsimonious. This analysis suggested independent losses of central teeth in several clades: most species of Pseudomelatomidae, Leucosyrinx Dall 1889, Horaclavidae and Terebridae, as well as in some species of Turridae and Clavatulidae.

The third and forth analyses were with alternative coding of the characters and with unordered and stepmatrix parsimony models correspondingly. Species with vestigial central structures were coded as having the broad unicuspid teeth. The reconstruction produced longer trees (15 and 20 steps, respectively), which were therefore rejected.

\section{Character 2. Lateral teeth of the radula (Fig 27).}

Lateral teeth are present in all outgroups. They are absent in Clade A and present in some groups of Clade B.

There are two major types of lateral teeth among the ingroup species in our tree. In Drilliidae they are well formed and multicuspid, completely separate from the central tooth (Figs 7-10). In all others (some Pseudomelatomidae, Turridae and Clavatulidae) they are very weak, plate-like, non-cuspidate and usually completely or partially fused with the central tooth (when it is present), forming the "central formation" (Kantor, 2006) (see the discussion below). In some groups the laterals are so weak that their presence can be revealed only by staining of the subradular membrane. This is particularly characteristic for Clavatulidae, in which they were first revealed by Kilburn (1985).

A first analysis with character states unordered suggested the absence of lateral teeth is ancestral for the Conoidea and independent appearance of the lateral teeth occurred independently in five clades (all in clade B). Since central teeth are present in outgroups these events would be considered as a reversions.

The second analysis was performed with reversions interdicted (Fig. 27) and resulted in a longer tree (17 steps vs 9 in the previous analysis). The analysis did not allow reconstruction of the single most parsimonious state for the entire Conoidea nor for Clade B since multicuspid neogastropod type teeth, unicuspid neogastropod type teeth and plate-like lateral teeth were equally parsimonious.

For most of clade B conoideans (except Cochlespiridae) the most parsimonious state was plate-like teeth, while multicuspid teeth seems to re-appear in the branch that combines Drilliidae and Pseudomelatomidae. Lateral teeth are independently lost in 
several lineages - in most species of Pseudomelatomidae, Horaiclavidae, Terebridae and others.

In all the species in our tree, the presence of the lateral teeth was combined with the presence of the central tooth, which is not the case for all conoideans (see discussion).

\section{Character 3. Morphology of the marginal teeth (Fig. 43).}

Despite great variability of the marginal teeth in Conoidea, four major types can be recognized:

a. duplex teeth, consisting of a major element (limb) attached to the subradular membrane along most of its length (Figs. 23-24- $\mathrm{ml}$ ) and the accessory limb, that is the thickened edge of the major element, usually more or less elevated above the membrane (Fig. 23-25 - al). These teeth demonstrate the great variability in shape (see Kantor, Taylor, 2000) (Figs. $28,30,33,34-42$ ) and have often been referred to as "wishbone" (e.g. Powell, 1966). The term was coined based on the misconception that the limbs are separate and the tooth is actually bifurcating, as it appears under the light microscope (most of Clade B). In some cases the limbs are nearly equally developed and the teeth attain a trough-shape, becoming "semienrolled" (see below, Figs. 25-26). In the analysis this condition was also coded as "duplex teeth".

b. flat simple plate-like teeth (some Drilliidae) (Fig. 7).

c. Solid, recurved teeth, attached to the membrane along part of the length, sometimes with a slightly broadened base that is actually attached to the membrane (some Pseudomelatomidae -- Pseudomelatoma, Hormospira Berry, 1958 and Tiariturris Berry, 1958 - Fig. 14; some Terebridae -Euterebra and Duplicaria - Fig. 48, the latter not represented in our tree).

d. Hypodermic teeth. These are hollow enrolled teeth (Figs. 47, 49, 50-53) attached to the subradular membrane only by a narrow base or through a flexible stalk, the ligament (Fig. 51) (some Borsoniidae, Conidae and others).

The analysis was not able to resolve the single most parsimonious state for the entire Conoidea, but suggested that a duplex tooth is the most parsimonious state for clade B. Flat teeth are characteristic only for some Drilliidae and according to the tree 
they are an autapomorphy of several species, thus suggesting their derivation from duplex teeth. Similarly, solid recurved teeth originated from duplex teeth twice independently in the evolutionary history of Conoidea - in some Pseudomelatomidae and Terebridae. Hypodermic teeth are a synapomorphy of clade A but also appeared independently in Terebridae. The marginal teeth have been also lost several times independently (at least three times in clade B and twice in Terebridae).

\section{Character 4. Morphology of duplex marginal teeth (Fig. 44).}

Duplex teeth are very variable in morphology. The difference in appearance is mainly determined by relative size and shape of the accessory limb, as well as the degree of its elevation above the surface of the subradular membrane. The representation of the taxa in our tree does not allow more detailed analysis, although the general patterns can be traced.

We recognize four subtypes of duplex teeth, although much more variation can be found in other Conoidea not included in our study.

The first subtype is characterized by equal or nearly subequal development of major and accessory limbs. This type of tooth is found in Cochlespiridae (Figs. 40-41) (represented only by two genera in our tree) in which the teeth are characterized by relatively large size of the accessory limb (Fig. 41 - al) that is of nearly the same size as the major limb (Fig. $41-\mathrm{ml}$ ). This produces the appearance of the tooth folded lengthwise. The analysis suggested that it is an apomorphy of the clade.

A similar subtype, although having a different appearance, is the so-called semienrolled tooth (Taylor et al., 1993; Kantor, Taylor, 2000). In this type the accessory limb is also subequal in size to the major limb (Figs. 25-26), but the lengthwise folding is much less tight and the teeth attain a trough-like shape. According to the analysis, this type of tooth appeared several times independently in clade B - in some genera of Pseudomelatomidae (in the clade Pilsbryspira McLean, 1971, Zonulispira Bartsch, 1950 and Pyrgospira McLean, 1971 - Fig. 21, and independently in Ptychobela Thiele, 1925 (Fig. 22), Cruziturricula Marks, 1951 (Fig. 11), Imaclava Bartsch, 1944, and Iotyrris (Turridae).

The most parsimonious plesiomorphic state for most of clade B (except Cochlespiridae) is the duplex marginal tooth with unequal sizes of the major, larger limb and smaller accessory limb ("unequal limbs" in Fig. 44). Depending on the degree of difference the tooth may look very different, in its most extreme state being nearly flat with a narrow and very slightly raised accessory limb (eg. Funa Kilburn, 1988 - Fig. 37). 
In most groups the accessory limb is comparatively large and the tooth edge adjoining the limb is significantly raised above the membrane, so that the accessory limb occupies the dorsal position on the major limb (eg. 20,39). Different teeth of this subtype have been thoroughly illustrated by Kantor et al. (1997) and Taylor et al. (1993).

A characteristic type of duplex tooth is found in the genera Comitas Finlay, 1926 and Knefastia Dall, 1919 (Figs. 16, 23). The teeth are nearly flat, broadly elongate, with the major limb thickened at the tip and along one side, while the accessory limb is represented by the narrow thickened margin of the tooth that does not reach the tip of the tooth but is inserted in a shallow and narrow socket, slightly overlaying the thickened part of the major limb.

The several following characters (5-8) apply to hypodermic teeth only.

Hypodermic teeth are hollow enrolled marginals, usually with overlapping edges (exemptions are some representatives of Mangeliidae - Fig. 50, not present in our dataset) and open at both the tooth base and near the tip. Teeth of this morphology are found mostly among representatives of clade $A$ and in most radulate Terebridae. Nevertheless, in at least one genus of Clavatulidae (Toxiclionella Powell, 1966) and in Cruziturricula the marginal teeth are very similar in anatomy (Figs. 11, 32). The major difference between hypodermic teeth in clade $A$ and Terebridae on one hand and in Toxiclionella and Cruziturricula on the other is the form of attachment to the radular membrane. In the former, the teeth are attached only by the base, while in the latter along most of their length. This suggests different evolutionary origins of such teeth (Kantor \& Taylor, 2000).

The anatomy of hypodermic teeth has been successfully used in the phylogenetic reconstructions of Conidae (Kohn et al., 1999) and high congruence was found between feeding type and tooth anatomy in Conus (eg. Duda et al., 2001). At the same time there is a limited number of characters, that are widespread across multiple families posessing hypodermic teeth.

\section{Character 5. Presence of a spur (Fig. 45).}

The basal spur is an anterior projection on the base of the tooth (Fig. 53). Its function is probably to tighten the grasp of the proboscis tip during feeding and thus to prevent premature loss of the tooth from the proboscis (Kohn et al., 1999). Our analysis 
suggested several independent origins of this character - in Conidae, Borsoniidae, Mangeliidae and Terebridae (Fig. 45).

\section{Character 6. Presence of a barb(s) (Fig. 54).}

A barb is a projection from the shaft of the tooth that has a cutting edge and joins the shaft at an acute angle (Fig. 52). There can be from 0 to 5 barbs (Conus californicus) (Kohn, Nishi \& Pernet, 1999). The analysis suggests that the barbs appeared independently in every family of clade A except Mitromorphidae, in which they are absent.

\section{Character 7. Presence of a blade (Fig. 55).}

The blade is a projection from the shaft of the tooth that has a cutting edge and joins the shaft at an obtuse angle (Kohn et al.,, 1999) (Fig. 53). In some cases the distinction between a barb and a blade is subtle. The analysis suggested that a blade originated independently twice - in clade A and in Terebridae. Presence of a blade was the most parsimonious ancestral state for clade A (Fig. 55).

\section{Character 8. Presence of a ligament (Fig. 56).}

The ligament is an elongate, flexible stalk, attached to the base of the tooth and to the membrane, when the latter is present (Fig. 51). In fresh radulae the ligament can be subcircular in cross-section, but when air-dried the ligament is usually flat and membrane-like. The presence of a ligament is often not recorded during radula description.

A ligament has so far only been recorded in clade $A$, and its presence is the most parsimonious ancestral state for the clade. It is present in Conidae, Borsoniidae, Mitromorphinae and at least in one species of Raphitomidae (Thatcheria mirabilis - see Taylor et al., 1993 -- fig. 23 c).

Character 9. Use of marginal teeth at the proboscis tip for stabbing prey (Fig. 57).

The analysis suggested that the use of marginal teeth at the proboscis tip is the most parsimonious plesiomorphic state for the entire Conoidea. 


\section{Discussion}

Origin of the conoidean feeding mechanism and general evolutionary trends

Use of separate marginal teeth one by one at the proboscis tip is one of the most intriguing characters of conoidean evolution. Taylor et al. (1993) suggested that conoidean feeding mechanisms gradually evolved within the group, but first appeared in the early stages of conoidean evolution. We traced the use of separate marginal teeth at the proboscis tip on a molecular tree using available published and unpublished anatomical data. As was mentioned in the introduction, the base of the tooth is held by special sphincter(s) and/or an epithelial pad of the buccal tube. Thus use of teeth at the proboscis tip can be inferred from anatomical characters (presence of the sphincters of the buccal tube). Although we do not have anatomical data for every species included in our analysis, they are available for species of most of the genera and for every family, allowing us to extrapolate to the remaining members of the clade. The analyses clearly suggested that the origin of the peculiar feeding mechanism is an apomorphy of Conoidea in general, and it appeared before the divergence of the two major clades ( $A$ and B) (Fig. 57).

The initial divergence of Conoidea into clades $A$ and $B$ (that is the clades with primarily hypodermic and primarily duplex marginal teeth, respectively) is an unexpected inference from the conoidean molecular phylogeny. In previous cladistic analyses based on morphological characters the representatives of clade A (referred to as family Conidae by Taylor et al., 1993) appeared as a terminal clade, suggesting the gradual transformation of radular morphology. The molecular-based results contradict this hypothesis.

Although there is no fundamental difference in feeding mechanism between clades $A$ and $B$, there are nevertheless important differences in the anatomy of the radular apparatus. In clade B, the radular apparatus consists of a more or less well-developed odontophore with supporting musculature (it is absent only in a few species that lack a radula, eg. Horaiclavus phaeocercus Sysoev, 2008, Horaiclavidae - Fedosov \& Kantor, 2008), moderately strong continuous radular membrane and (not always) presence of central and/or lateral teeth. An important character of the radula is that the marginal teeth are attached to the membrane along a significant or even most of their length. Exceptions are some Terebridae (discussed below). 
In clade A an odontophore with muscles is absent and the subradular membrane is very thin to vestigial. The teeth are attached to the membrane only by the very narrow base of the tooth, sometimes through a flexible stalk - the ligament. The attachment of the marginal tooth (of hypodermic type) to the membrane only by the base facilitates rolling of the tooth, which may be formed by a few completely overlapping rolls in Conidae (for more details see Kantor \& Taylor, 2000), although usually the edges of the tooth plate are only slightly overlapping (Fig. 51 - cross sections through the tooth). Thus the molecular analysis suggests that appearance of the conoidean feeding mechanism was the key apomorphy of the superfamily. We suggest that it may have greatly improved prey capture and allowed rapid diversification and species radiation that resulted in the modern hyperdiverse group that includes about 4600 Recent described species and a larger number of still unnamed ones (Bouchet et al., 2009). The splitting of Conoidea into two groups with different radular types and foregut anatomies was the first major evolutionary event, taking place at the earliest stage of evolution of the group after the initial appearance of the unique feeding mechanism.

\section{Transformation of the non-hypodermic marginal teeth (clade B)}

Non-hypodermic marginal teeth are found in clade B and are very variable, although they can be reduced to 3 major morphological types - duplex (including semienrolled), solid recurved and flat simple plate-like.

The solid recurved teeth were previously considered as the prototype marginal teeth in Conoidea (eg. Kantor \& Sysoev, 1990) and with the exception of three genera, which were united in the Pseudomelatomidae (sensu Taylor et al., 1993), were also found in some Terebridae (genera Duplicaria and Euterebra). The tooth morphology in these two lineages is very similar. Plotting the character on a molecular tree clearly indicated that this tooth type appeared independently twice and analysis suggested that this type of marginal tooth developed secondarily from duplex teeth. Some important differences can also be mentioned: in Pseudomelatomidae sensu Taylor et al., 1993 the radula is long (about 100 rows of teeth in Tiariturris) and possesses large and broad unicuspid central teeth; in Terebridae with these solid recurved teeth the radula is short (about 20 rows of teeth) and lacks the central teeth.

The functioning of this type of radula remains largely unknown. The shape of the rather strongly recurved teeth precludes their use separately at the proboscis tip. In Duplicaria and Euterebra the venom gland as well as proboscis is absent, while the 
odontophore is present (Rudman, 1969; Taylor, 1990). In Pseudomelatoma and Hormospira the venom gland is present and well developed, the proboscis is long, but the buccal tube lacks the sphincter that can hold the tooth (Kantor, 1988).

The three genera comprising Pseudomelatomidae sensu Taylor et al., 1993 (and encompassing only six Recent species) have very limited distribution - all are found in the Panamic province. It is possible that they comprise a local radiation connected to a shift to some peculiar type of prey, although this needs further confirmation. The presence of a large odontophore suggests that radulae with solid recurved marginal teeth are primarily used as an entire organ (probably for tearing and rasping the prey). In contrast, Terebridae with this type of radula (Taylor, 1990) have a broad distribution in the Indo-Pacific - species are found from South Africa to Japan, including the Solomon Islands and Oman, and some species have a broad Indo-Pacific distribution. They lack a proboscis and venom gland and probably are more general feeders, involving their long labial tube in prey capture.

Flat marginal teeth have also been considered as a prototype for the duplex teeth (Taylor et al., 1993) and were found in some Drilliidae (among the genera used in our analysis in Agladrillia, Splendrillia and Cerodrillia). The analysis demonstrates that this condition is autapomorphic and this type of tooth most probably originated by simplification of the duplex teeth, the presence of which is the plesiomorphic state for the entire clade $B$ and Drilliidae in particular.

Within the most common duplex type of marginal teeth many different morphologies can be recognized (Figs. 16-21, 34-42), although they are very similar in mode of formation. Kantor \& Taylor (2000) studied maturing teeth along the radular membrane and showed that they develop from a flat plate by thickening of the tooth edges and elevation of the posterior edge (additional limb) from the membrane. This thickening of the margins of duplex teeth, folding along the length and partial enrolling (in the semi-enrolled teeth) can be explained as features that provide mechanical strength. In mechanical terms, a simple flat plate is less stiff and more likely to buckle when subject to a compressive force, than one with thickened edges or a hollow cylinder (Wainwright et al., 1976). Teeth used at the proboscis tip need to be rigid to pierce the prey's integument.

Although marginal tooth shape appeared to be rather homoplastic, it is characteristic for some of the well defined clades. For example, in Cochlespiridae the accessory limb is large, nearly equal in size to the major limb. Therefore the tooth appears to be folded lengthwise with a solid tip. Clavatulidae also possess rather 
distinctive duplex teeth with a sharp-edged major limb and a deep socket where an accessory limb is inserted, often with angulation distal to the socket. The well-supported clade including genera Pilsbryspira, Zonulispira, and Pyrgospira is characterized by semi-enrolled teeth with a similar shape and was previously considered a separate subfamily Zonulispirinae. In some duplex teeth (eg. in Funa and Cheungbeia) the secondary limb is minute, nearly obsolete. Kantor \& Taylor (2000) suggested, based on a morphological tree, that this is a derived state. The current analysis confirms this hypothesis.

In the single genus Toxiclionella Powell, 1966 (not present in our analysis), referred to Clavatulidae and that still possesses an odontophore, the teeth are hardly distinguishable from true hypodermic teeth (Fig. 32) having two barbs at the tip and a subterminally opening tooth canal. The marginal teeth are attached to the membrane along most of their length, similarly to other species of clade B.

\section{Transformations of the central radular segment (Clade B)}

The peculiar feeding mechanism of Conoidea is associated with the anatomy of the foregut. In all Conoidea the buccal mass with the radular diverticulum (and odontophore with muscles in clade B) is situated at the proboscis base and often behind proboscis in its contracted state. The odontophore cannot be protruded through the mouth and therefore the radula has limited function as an integrated whole organ in most conoideans. A few exceptions occur sporadically in different clades. In these groups the buccal mass is secondarily shifted anteriorly or is able to evert through the mouth along with the walls of the buccal tube (eg in Funa latisinuata - Taylor et al., 1993, fig. 14).

The limited functioning of the radula as an integrated organ in adults is indirectly confirmed our not observing traces of worn teeth (marginal, and central or laterals when present) in radulae examined by us (except Drilliidae, see below). Thus the central and lateral teeth are hardly functional in Conoidea (while the marginals detached from the membrane are used individually at the proboscis tip) and therefore the adaptive value of their morphological transformations may be reduced. This may explain the high variability of the morphology of the central segment of the radula that includes the central and lateral teeth.

In general the evolutionary transformation of the central (and lateral teeth) in clade $B$ is complicated. Analysis of the morphology of the central tooth with unordered 
character states produced a shorter tree, but suggested initial reduction of the tooth in the entire Conoidea and subsequent multiple (eight in our dataset) independent reappearances in different clades, that is multiple reversions (Fig. 5). This is not highly parsimonious and it is especially difficult to explain these reversions from a functional point of view due to the limited functions of the central and lateral teeth. On the contrary, non-functionality of the central segment seems to be congruent with reduction and complete loss of the central segment in different lineages as was suggested by the stepmatrix analysis (Fig. 6).

Similarly we found the numerous losses of the lateral teeth (stepmatrix analysis Fig. 27) more probable (although less parsimonious) than initial reduction of the teeth in the entire Conoidea and independent re-appearance in five clades (analysis with unordered character states). Only in Drilliidae do the lateral teeth seem to be functional (see below), while in other clades they are very weak plate-like structures, sometimes appearing only as inconspicuous thickenings of the subradular membrane (eg in Pusionella compacta - Fig. 29, vit).

The central tooth is a highly variable structure in Conoidea, ranging from very narrow unicuspid to broad with a large cusp and well developed lateral flaps. Kantor \& Sysoev (1991) and Taylor et al. (1993) suggested that the broad central tooth in some groups may be the result of fusion of paired lateral teeth with the narrow unicuspid central tooth. In some species, attributed here to Pseudomelatomidae (Crassiclava turricula - Figs. 19-20, Antiplanes sanctiioannis (Smith, 1875) - Kantor \& Sysoev, 1991, figs. 27-28; Comitas onokeana vivens Dell, 1956 - Fig. 15), clearly separate plateshaped lateral teeth without cusps were found. In these species the central tooth (cusp) is absent. In Comitas Finlay, 1926 and the related genus Knefastia Dall, 1919 intermediate stages can be found. In K. tuberculifera in addition to a very weak and reduced central tooth (Fig. 18, ct) vestigial lateral plates (teeth) can be observed (vlt); in Comitas pachycercus Sysoev et Bouchet, 2001, Comitas murrawolga (Garrard, 1961) and Comitas sp. (Figs. 16-17) the central structure looks like a well defined central tooth with a narrow cusp and broad lateral flaps. This transition row in closely related species suggests a composite structure of the "central tooth" in this group, formed by fusion of the central narrow tooth with cuspless laterals. Kantor (2006), after examination of the radula of 64 species from 7 genera of Turrinae (= Turridae in the current classification), confirmed the composite structure of the "central" tooth, which is formed by the fusion of central and lateral teeth and suggested calling this structure the "central formation". In Turridae transitional conditions ranging from a clearly tripartite structure with a gap 
between the cusp (=central tooth) and the lateral flaps (=lateral teeth) to a seemingly solid central tooth occur, sometimes within a single genus. This range can be illustrated by the different species of Turridrupa Hedley, 1922 (see Kantor, 2006, fig. 4) or Gemmula (herein, Fig. 58-63). In Gemmula unilineata Powell, 1967 the central tooth is well separated from the narrow laterals (Figs. 58-59); in Gemmula sp. 3 (sensu Kantor 2006) the lateral teeth are close to the central tooth, but separated by gaps (indicated by arrows on Fig. 63), and finally in Gemmula rarimaculata the lateral and central teeth are fused (Figs. 60-61). Finally in three clades - in Cochlespiridae, in that combining Pseudomelatoma and Tiariturris (Pseudomelatomidae sensu Taylor et al., 1993), and in Gemmuloborsonia there is no indication that the central tooth has a composite origin. The posterior margin, bearing the cusp is equally developed along its width and elevated over the radular membrane. Without further information we conclude that these groups possess the broad unicuspid central tooth, while the lateral teeth are absent. This conclusion could be rebutted by observations of embryonic development of the radula, that may demonstrate a composite structure of the central teeth.

One of the unexpected results of our analysis is the possible secondary origin of the multi-cuspidate separate and well formed lateral teeth in Drilliidae. Previously this type of the tooth was considered prototypic for turrids (Powell, 1966; Kantor, Sysoev, 1991), and this hypothesis was the rationale for placing the Drilliidae as a separate family from the other Turridae sensu Taylor et al. 1993. According to the analysis, the multicuspid lateral teeth may be the ancestral state for clade B; they then disappeared and re-appeared again in the Drilliidae plus Pseudomelatomidae clade, though multicuspid teeth are present only in the former family. However, different runs of the analysis with different coding of radular character states in the outgroups suggested different most parsimonious plesiomorphic conditions in clade B, but in none of the runs were multicuspid teeth the single plesiomorphic state. One of the reasons for these inconclusive results may be the fact that the homology of different teeth in Neogastropoda (including outgroups) is not yet finally established and the relationships within the entire Neogastropoda are far from resolved.

From a general point of view it seems more probable that well pronounced multicuspid lateral teeth in Drilliidae is the plesiomorphic condition in Conoidea, retained due to peculiarities of their feeding mechanism. Unfortunately there is practically no information on the diet and radula functioning of drilliids. The only published record is that of Maes (1983) of the gut content of Drillia cydia (Bartsch, 1943). Finding intact prey (sipunculid) in the posterior oesophagus suggested that the radula is used for 
gripping and/or piercing, not rasping or tearing. Drilliidae studied by us possess large and powerful odontophores, which may suggest active use of the radula as an intgegrated whole organ. To confirm this we carefully examined the bending plane of the radulae. In many species the laterals and even the central teeth were badly damaged (Fig. 12 - broken parts of the teeth are marked by small arrows); damage on the marginal teeth in the same specimens was not observed. These observations suggest that lateral (and even small central) teeth are functional, but without additional data on feeding in this group it is impossible to draw any final conclusions about the mode of functioning.

One important question remains: why in clade B conoideans, which possess in general the same feeding mechanism as clade A species, are the odontophore and its musculature retained? The odontophore varies in size from large in Drilliidae and some Pseudomelatomidae (Pseudomelatoma) (Taylor et al., 1993) to very small or nearly obsolete (eg. in some Hindsiclava, Pseudomelatomidae - Kantor et al., 1997). There are no data that explain this phenomenon. From what has been said above it is clear that the functioning of the radula as an ingtegrated organ may be limited, possibly to transferring the swallowed prey from the buccal cavity, situated at the proboscis base, further to oesophagus. Only in very few conoideans is the buccal cavity plus radula either shifted to the proboscis tip or able to evert through the mouth (for details see Taylor et al., 1993). From the point of view of speciation, clade A conoideans are more diverse, including 202 genera (not counting 82 genera recognized in the Conidae, the phylogeny and taxonomy of which is not yet finally revised) versus 180 genera in clade $B$. Thus absence of the odontophore does not seem to limit prey capture and feeding. Moreover, clade A conoideans seem to have a broader prey range, including other gastropods (numerous Conus species) and bivalves (Phymorhynchus, Raphitomidae Fujikura et al., 2004) and even fish (several species of Conus).

In some species of Conus there are ontogenetic changes of radular teeth probably related to changes in diet (summarized by Nybakken, 1990) and therefore in prey capture mechanism. We may imagine that similar changes can occur in clade B and that the prey capture and feeding mechanisms may differ between young individuals and adults and that at some ontogenetic stage the odontophore may be fully operational. This supposition needs careful research to detect any ontogenetic radular and foregut anatomy changes. 
Hypodermic marginal teeth are found in clade A and some Terebridae. The morphology of the hypodermic teeth is extremely variable and was traditionally used for taxonomy. Some hypodermic teeth are very simple, semi-enrolled. Such teeth are found among Mangeliidae (eg. Mangelia - Fig. 50). Unfortunately none of these species is present in our molecular tree.

The hypodermic teeth of Conidae s.s. have been described in great detail and correlation between tooth morphology and diet has been demonstrated (eg. Nybbaken, 1990). The representation of genera in our data matrix is relatively sparse and therefore we could only trace a limited number of characters of the hypodermic teeth. It appeared that the spurs and barbs of the teeth are homoplasic and evolved independently several times. No clear trends were obvious, possibly due to the incompleteness of our dataset.

\section{Terebridae radiation}

One of the most remarkable findings of the molecular analysis (Puillandre et al., 2008,2011 ) is that the Terebridae do not represent a totally separate lineage, but are included in clade B and are probably sister to the Turridae. Consequently, the evolutionary history of radular transformation is rather different from that traditionally accepted.

Common among all terebrids is complete loss of the central and lateral teeth. In our analysis the first taxon to diverge among the Terebridae is Euterebra tristis (Deshayes, 1859), characterized by the solid recurved teeth, superficially similar to that in Pseudomelatoma and related genera (Pseudomelatomidae). Our analysis was not able to resolve the most parsimonious ancestral state for Terebridae. Before the molecular analysis of all Conoidea was performed (Puillandre et al., 2011), more detailed analysis of Terebridae has been conducted (Holford et al., 2009). Among other things it revealed that Pellifronia jungii (Lai, 2001) might be sister group to all the other Terebridae (recent analyses confirm that $P$. jungi, E. tristis and all the other Terebridae represent three distinct lineages, among which $P$. jungi is sister-group of a clade including E. tristis and all the other Terebridae - Castelin unpublished results). The radula of $P$. jungi appeared to have a new type of marginal teeth for the family, similar in general arrangement to the duplex teeth of other families in clade B (Fig. 46). The species possess a venom gland with a muscular bulb proboscis and small odontophore. 
Thus within the Terebridae the entire transition can be found from species with duplex teeth with a strong subradular membrane (and an odontophore) through solid recurved teeth to species with typical hypodermic teeth, attached only by their bases to a vestigial membrane (similar to the arrangement of the marginal teeth in clade $A$ and similarly lacking an odontophore). There are some species (not included in our analysis, but whose position was inferred in the molecular phylogeny of Holford et al. 2009), eg. Impages hectica (Linnaeus, 1758), that possess hypodermic teeth (penetrated by numerous holes - Fig. 49) that are attached to a rather strong membrane along their length, a condition similar to that in Toxiclionella (Clavatulidae).

Within this single clade the radula transformation repeats the evolution of the radular apparatus within the entire Conoidea. This is a remarkable example of the radular evolvability in Conoidea.

\section{Acknowledgements}

Material for this study was collected during a number of field trips and expeditions. The PANGLAO 2004 Marine Biodiversity Project was funded by the Total Foundation and the French Ministry of Foreign Affairs, the MNHN-IRD-PNI Santo 2006 expedition was made possible by grants, among others, from the Total Foundation and the Stavros Niarchos Foundation, and the AURORA 2007 cruise was made possible through a grant from the Lounsbery Foundation. The Coral Sea and Solomon Islands cruises took place on board R/V Alis deployed from Nouméa by the Institut de Recherche pour le Développement (IRD), and Bertrand Richer de Forges was cruise leader for the Solomons, Coral Sea and Vanuatu expeditions. Ellen Strong, Marie-Catherine Boisselier and Sarah Samadi are thanked for their role in molecular sampling during these expeditions. Cruises in the Gulf of Panama (2000) and the Lower Florida Keys (2001) were on R/V Urraca and R/V Bellows, respectively, and we thank the captain and crew of each and the respective expedition leaders H. Lessios (STRI, Panama) and T. Collins (FIU, Miami).

Work was conducted in Paris by YK during visits under the MNHN visiting curatorship programme. He expresses his thanks to Virginie Héros, Barbara Buge, Philippe Maestrati and Pierre Lozouet for assistance during his time in Paris. This work was supported by a grant from the Russian Foundation of Basic Research (RFBR) 1104-01284-a 'Evolution of digestive system of carnivorous gastropods: testing of morphologically-based hypotheses by molecular data' (PI Y.Kantor). 
The senior author conducted much of the study of the radulae of the Conoidea in co-authorship with John Taylor and some of the images have been reproduced here and used in discussion. We thank Dr. Alexander Fedosov for his comments on the manuscript. Dr. Robert Cowie assisted in editing of the manuscript.

\section{References}

Bandel, K., 1984, The radulae of Carribean and other Mesogastropoda and Neogastropoda. Zoologische Verhandelingen, 214: 1-188, 22 pls.

Bouchet, P., Y. Kantor, A. Sysoev \& N. Puillandre, 2011, A new operational classification of the Conoidea (Mollusca, Gastropoda). Journal of Molluscan Studies, in press.

Bouchet, P., P. Lozouet \& A. Sysoev, 2009, An inordinate fondness for turrids. Deepsea research. Part II-Topical studies in oceanography, 56, issue 19-20: 1724-1731.

Duda, T.F., A.J. Kohn \& S.R. Palumbi, 2001, Origins of diverse feeding ecologies within Conus, a genus of venomous marine gastropods. Biological Journal of the Linnean Society, 73: 391-409.

Duda, T.F. \& A.J. Kohn, 2005, Species-level phylogeography and evolutionary history of the hyperdiverse marine gastropod genus Conus. Molecular Phylogenetics and Evolution, 34: 257-272.

Espiritu, D.J.D., M.Watkins, V. Dia-Monje, G.E. Cartier, L.E. Cruz, \& B.M. Olivera, 2001, Venomous cone snails: molecular phylogeny and the generation of toxin diversity. Toxicon, 39: 1899-1916.

Fedosov, A. \& Yu. Kantor, 2008, Toxoglossan gastropods of the subfamily Crassispirinae (Turridae) lacking a radula, and a discussion of the status of the subfamily Zemaciinae. Journal of Molluscan Studies, 74: 27-35.

Fujikura, K., T. Sasaki, T. Yamanaka \& T. Yoshida, 2009, Turrids whelk, Phymorhynchus buccinoides feeds on Bathymodiolus mussels at a seep site in Sagami Bay, Japan. Plankton \& Benthos Research, 4: 23-30.

Heralde III, F. M., Yu. I. Kantor, M. A. Q. Astilla, A. O. Lluisma, R. Geronimo, P. M. Aliño, M. Watkins, P. S. Corneli, B. M. Olivera, A. D. Santos \& G. P. Concepcion, 2010, The Indo-Pacific Gemmula species in the subfamily Turrinae: Aspects of field distribution, molecular phylogeny, radular anatomy and feeding ecology. Philippine Science Letters, 3: 21-34. 
Heralde, F.M., M.Watkins, J.-P. Ownby, P.K. Bandyopadhyay, A.D. Santos, G.P. Concepcion \& B.M. Olivera, 2007, Molecular phylogeny of some Indo-Pacific genera in the subfamily Turrinae $\mathrm{H}$. Adams and A. Adams, 1853 (1838) (Gastropoda: Neogastropoda). Nautilus, 121: 131-138.

Hughes, R.N. \& W.K. Emerson, 1987, Anatomical and taxonomic characteristics of Harpa and Morum (Neogastropoda: Harpaidae). Veliger, 29: 349-358.

Holford, M., N. Puillandre, Y. Terryn, C. Cruaud, B.M. Olivera \& P. Bouchet, 2009, Evolution of the Toxoglossa Venom Apparatus as Inferred by Molecular Phylogeny of the Terebridae. Molecular Biology and Evolution, 26: 15-25

Kantor, Yu.I., 1988, On the anatomy of Pseudomelatominae (Gastropoda, Toxoglossa, Turridae) with notes of functional morphology and phylogeny of the subfamily. Apex, 3: 1-19.

Kantor, Yu.I., 2006, On the morphology and homology of the "central tooth" in the radulae of Turrinae (Conoidea: Turridae). Ruthenica, 16: 47-52.

Kantor, Yu.I., 2007, How much can Conus swallow? Observations on molluscivorous species. Journal of Molluscan Studies, 73: 123-127.

Kantor, Y. I., A. Medinskaya \& J. D. Taylor, 1997, Foregut anatomy and relationships of the Crassispirinae (Gastropoda, Conoidea). Bulletin of the Natural History Museum, London (Zoology), 63: 55-92.

Kantor, Yu.I. \& A.V. Sysoev, 1989, On the morphology of toxoglossan gastropods lacking a radula, with a description of new species and genus of Turridae. Journal of Molluscan Studies, 55: 537-549.

Kantor, Yu.I. \& A.V. Sysoev, 1990, Peculiarities of the morphology and evolution of the anterior part of the digestive system of Toxoglossa. Pp. 91-134, in O.L.Rossolimo, ed., Evolutionary morphology of molluscs (Regularities of morpho-functional changes of radular apparatus). Moskva, Izdatel'stvo Moskovskogo Universiteta.

Kantor, Yu.I. \& A.V. Sysoev, 1991,Molluscs of the genus Antiplanes (Gastropoda, Turridae) of the northwestern Pacific Ocean. Nautilus, 105: 119-146.

Kantor, Y. I. \& J. D. Taylor, 1991, Evolution of the toxoglossan feeding mechanism: new information on the use of the radula. Journal of Molluscan Studies, 57: 129-134.

Kantor, Y. I. \& J. D. Taylor, 1994, The foregut anatomy of Strictispira paxillus. Journal of Molluscan Studies, 60: 343-346.

Kantor, Y. I. \& J. D. Taylor, 2000, Formation of marginal radular teeth in Conoidea (Neogastropoda) and the evolution of the hypodermic envenomation mechanism. Journal of Zoology, London, 252: 251-262. 
Kantor, Y. I. \& J. D. Taylor, 2002, Foregut anatomy and relationships of raphitomine gastropods (Gastropoda: Conoidea: Raphitominae). Bollettino Malacologico, Supplement 5: 161-174.

Kilburn, R.N., 1985, Turridae (Mollusca: Gastropoda) of southern Africa and Mozambique. Part 2. Subfamily Clavatulinae. Annals of the Natal Museum, 26: 417-470.

Kohn, A. J., 1956, Piscivorous gastropods of the genus Conus. Proceedings of the National Academy of sciences of the United States of America, 42: 168-171.

Kohn, A. J., 1990. Tempo and mode of evolution in Conidae. Malacologia, 32: 55-67.

Kohn, A. J., M. Nishi \& B. Pernet, 1999, Snail spears and scimitars: a character analysis of Conus radular teeth. Journal of Molluscan Studies, 65: 461-481.

Maddison, W. P. \& D.R. Maddison, 2007-2010, Mesquite: a modular system for evolutionary analysis. Version $2.74 \mathrm{http} / / /$ mesquiteproject.org

McLean, J.H., 1971, A revised classification of the family Turridae, with the proposal of new subfamilies, genera, and subgenera from the Eastern Pacific. Nautilus, 14: 114-130.

Miller, J.A., 1989, The toxoglossan proboscis: structure and function. Journal of Molluscan Studies, 55: 167-182.

Miller, J.A., 1990, The feeding and prey capture mechanism of Turricula nelliae spurius (Hedley) (Gastropoda: Turridae). Pp. 979-992, in B. Morton, ed., Proceedings of the Second International Marine Biological Workshop: The marine Flora and Fauna of Hong Kong and Southern China, Hong Kong, 1986. Hong Kong University Press, Hong Kong.

Nybakken, J, 1990, Ontogenetic change in the Conus radula, its form, distribution among the radula types, and significance in systematics and ecology. Malacologia, 32: 35-54.

Olivera, B.M., 2006, Conus peptides: biodiversity-based discovery and exogenomics. Journal of Biological Chemistry, 281: 31173-31177.

Olivera, B. M., J. Rivier, C. Clark, C. A. Ramilo, G. P. Corpuz, F. C. Abogadie, E. E. Mena, S. R. Woodward, D. R. Hillyard \& L. J. Cruz, 1990,. Diversity of Conus neuropeptides. Science, 249: 257-263.

Powell, A.W.B., 1966, The molluscan families Speightiidae and Turridae. An evaluation of the valid taxa, both recent and fossil, with lists of characteristics species. Bulletin of the Auckland. Institute and Museum, 5: 5-184. 
Puillandre, N. \& M. Holford, 2010. The Terebridae and teretoxins: combining phylogeny and anatomy for concerted discovery of bioactive compounds. BMC Chemical Biology, 10, 7.

Puillandre N., S. Samadi, M.-C. Boisselier, A.V. Sysoev, Y.I. Kantor, C. Cruaud, A. Couloux \& P. Bouchet, 2008, Starting to unravel the toxoglossan knot: molecular phylogeny of the "turrids" (Neogastropoda: Conoidea). Molecular Phylogenetics and Evolution, 47: 1122-1134.

Puillandre N., Y. Kantor, A. Sysoev, A. Couloux, C. Meyer, T. Rawlings, J. Todd \& P. Bouchet, 2011, The dragon tamed? A molecular phylogeny of the Conoidea (Mollusca, Gastropoda). Journal of Molluscan Studies, in press.

Rudman, W.B., 1969, Observations of Pervicacia trisits (Deshayes, 1859) and a comparison with other toxoglossan gastropods. Veliger, 12: 53-64.

Shimek, R. L. \& A. J. Kohn, 1981, Functional morphology and evolution of the toxoglossan radula. Malacologia, 20: 423-438.

Sysoev, A.V. \& Yu.I. Kantor, 1987, Deep-sea gastropods of the genus Aforia (Turridae) of the Pacific: species composition, systematics, and functional morphology of the digestive system. Veliger, 30: 105-126.

Sysoev, A.V. \& Yu.I. Kantor, 1989, Anatomy of molluscs of the genus Splendrillia (Gastropoda: Toxoglossa: Turridae) with description of two new bathyal species of the genus from New Zealand. New Zealand Journal of Zoology, 16: 205-214.

Taylor, J. D., Y. I. Kantor \& A. V. Sysoev, 1993, Foregut anatomy, feeding mechanisms, relationships and classification of the Conoidea (= Toxoglossa) (Gastropoda). Bulletin of the Natural History Museum, London (Zoology), 59: 125-170.

Taylor, J. D., 1990, The anatomy of the foregut and relationships in the Terebridae. Malacologia 32: 19-34.

Tucker, J.K. \& M.J. Tenorio, 2009, Systematic classification of recent and fossil Conoidean gastropods. Conchbooks, Hackenheim, Germany. 296 pp.

Wainwright, S. A., W. D. Biggs, J. D. Currey \& J. M. Gosline, 1976, Mechanical design in organisms. London: Edward Arnold. 423 pp. 
Table 1. List of characters states used in the analysis

\begin{tabular}{|c|c|c|c|c|c|c|}
\hline \multirow{2}{*}{$\begin{array}{l}\text { Number } \\
\text { of } \\
\text { character }\end{array}$} & \multirow{2}{*}{$\begin{array}{l}\text { Charater } \\
\text { description }\end{array}$} & \multicolumn{5}{|c|}{ Character states } \\
\hline & & 0 & 1 & 2 & 3 & 4 \\
\hline 1 & $\begin{array}{c}\text { morphology of } \\
\text { central tooth }\end{array}$ & absent & $\begin{array}{l}\text { multicuspid } \\
\text { of } \\
\text { caenogastro } \\
\text { pod type }\end{array}$ & $\begin{array}{l}\text { multicuspid } \\
\text { of } \\
\text { neogastropo } \\
\text { d type }\end{array}$ & $\begin{array}{l}\text { unicuspid } \\
\text { narrow }\end{array}$ & $\begin{array}{l}\text { unicuspid } \\
\text { broad }\end{array}$ \\
\hline 2 & $\begin{array}{l}\text { morphology of } \\
\text { the lateral teeth }\end{array}$ & absent & $\begin{array}{c}\text { cuspidate of } \\
\text { caenogastro } \\
\text { pod type }\end{array}$ & $\begin{array}{c}\text { cuspidate of } \\
\text { neogastropo } \\
\text { d type }\end{array}$ & $\begin{array}{l}\text { unicuspid of } \\
\text { neogastropo } \\
\text { d type }\end{array}$ & plate-like \\
\hline 3 & $\begin{array}{c}\text { morphology of } \\
\text { the marginal } \\
\text { teeth }\end{array}$ & absent & $\begin{array}{l}\text { non-duplex } \\
\text { (flat) }\end{array}$ & $\begin{array}{l}\text { duplex or } \\
\text { semi- } \\
\text { enrolled }\end{array}$ & $\begin{array}{l}\text { solid, } \\
\text { recurved }\end{array}$ & hypodermic \\
\hline 4 & $\begin{array}{c}\text { duplex marginal } \\
\text { teeth }\end{array}$ & $\begin{array}{c}\text { marginal } \\
\text { teeth absent }\end{array}$ & $\begin{array}{l}\text { teeth with } \\
\text { unequal } \\
\text { limbs }\end{array}$ & $\begin{array}{l}\text { teeth with } \\
\text { subequal } \\
\text { limbs }\end{array}$ & $\begin{array}{l}\text { teeth of } \\
\text { Comitas } \\
\text { type }\end{array}$ & $\begin{array}{c}\text { semi- } \\
\text { enrolled }\end{array}$ \\
\hline 5 & $\begin{array}{c}\text { details of } \\
\text { hypodermic } \\
\text { marginal teeth - } \\
\text { spur }\end{array}$ & absent & present & $\begin{array}{l}\text { hypodermic } \\
\text { teeth absent }\end{array}$ & & \\
\hline 6 & $\begin{array}{c}\text { details of } \\
\text { hypodermic } \\
\text { marginal teeth - } \\
\text { barbs }\end{array}$ & absent & $\begin{array}{c}\text { one barb } \\
\text { present }\end{array}$ & $\begin{array}{l}\text { two barbs } \\
\text { present }\end{array}$ & $\begin{array}{c}\text { three or } \\
\text { more barbs } \\
\text { present }\end{array}$ & $\begin{array}{l}\text { hypodermic } \\
\text { teeth absent }\end{array}$ \\
\hline 7 & $\begin{array}{c}\text { details of } \\
\text { hypodermic } \\
\text { marginal teeth - } \\
\text { blade }\end{array}$ & absent & present & $\begin{array}{l}\text { hypodermic } \\
\text { teeth absent }\end{array}$ & & \\
\hline 8 & $\begin{array}{c}\text { details of } \\
\text { hypodermic } \\
\text { marginal teeth - } \\
\text { ligament }\end{array}$ & absent & present & $\begin{array}{l}\text { hypodermic } \\
\text { teeth absent }\end{array}$ & & \\
\hline 9 & $\begin{array}{c}\text { use of marginal } \\
\text { teeth at } \\
\text { proboscis tip }\end{array}$ & $\begin{array}{l}\text { separate } \\
\text { tooth used } \\
\text { at the } \\
\text { proboscis tip }\end{array}$ & $\begin{array}{c}\text { separate } \\
\text { tooth not } \\
\text { used at the } \\
\text { proboscis tip }\end{array}$ & $\begin{array}{c}\text { marginal } \\
\text { teeth absent }\end{array}$ & & \\
\hline
\end{tabular}


Table 2. List of specimens (+ -- data available, - -- data unavailable)

\begin{tabular}{|c|c|c|c|c|c|}
\hline Family & Genus & species & $\begin{array}{c}\text { Institutional registration } \\
\text { number }\end{array}$ & Expedition/locality, station and depth & $\begin{array}{l}\text { Radula preparation, or source of } \\
\text { information }\end{array}$ \\
\hline Borsoniidae & $\begin{array}{c}\text { Bathytoma } \\
\text { Borsonia } \\
\text { Borsoniidae gen. } 1 \\
\text { Genota } \\
\text { Microdrillia } \\
\text { Tomopleura } \\
\text { Typhlomangelia (cf.) } \\
\text { Zemacies }\end{array}$ & $\begin{array}{l}\text { neocaledonica Puillandre, et al., } 2010 \\
\text { sp. } \\
\text { sp. } \\
\text { mitriformis (Wood, 1828) } \\
\text { cf. optima (Thiele, 1925) } \\
\text { reevii (C.B. Adams, 1850) } \\
\text { sp. } \\
\text { excelsa Sysoev \& Bouchet, } 2001\end{array}$ & $\begin{array}{l}\text { MNHN IM200717857 } \\
\text { MNHN IM200717932 } \\
\text { MNHN IM200717911 } \\
\text { MNHN IM200742293 } \\
\text { MNHN IM200717887 } \\
\text { MNHN IM200717875 } \\
\text { MNHN IM200717931 } \\
\text { MNHN IM200911056 }\end{array}$ & $\begin{array}{c}\text { EBISCO, CP2551, } 21^{\circ} 060^{\prime} \mathrm{S}, 158^{\circ} 350^{\prime} \mathrm{E}, 637-650 \mathrm{~m} \\
\text { Salomon 2, CP2197, } 8^{\circ} 24.40^{\prime} \mathrm{S}, 159^{\circ} 22.50^{\prime} \mathrm{E}, 897-1057 \\
\text { Panglao 2005, CP2333, 9 } 38.20^{\prime} \mathrm{N}, 123^{\circ} 43.50^{\prime} \mathrm{E}, 584-596 \mathrm{~m} \\
\text { Angola, AF7, Pta. Das Lagostas } \\
\text { Panglao 2004, T36, } 9^{\circ} 29.30^{\prime} \mathrm{N}, 123^{\circ} 51.50^{\prime} \mathrm{E}, 95-128 \mathrm{~m} \\
\text { Panglao 2004, T26, } 99^{\circ} 43.30^{\prime} \mathrm{N}, 123^{\circ} 48.80^{\prime} \mathrm{E}, 123-135 \mathrm{~m} \\
\text { Salomon 2, CP2269, } 7^{\circ} 45.10^{\prime} \mathrm{S}, 156^{\circ} 56.30^{\prime} \mathrm{E}, 768-890 \mathrm{~m} \\
\text { Musorstom 4, DW226, } 22^{\circ} 47^{\prime} \mathrm{S}, 167^{\circ} 22^{\prime} \mathrm{E}, 395 \mathrm{~m}\end{array}$ & $\begin{array}{c}+ \\
+ \\
+ \\
+ \\
- \\
- \\
- \\
\text { Radula-less species }\end{array}$ \\
\hline Clathurellidae & $\begin{array}{l}\text { Clathurella } \\
\text { Etrema } \\
\text { Nannodiella }\end{array}$ & $\begin{array}{l}\text { nigrotincta (Montrouzier, 1872) } \\
\text { cf. tenera (Hedley, 1899) } \\
\text { ravella (Hedley, 1922) }\end{array}$ & $\begin{array}{l}\text { MNHN IM200742607 } \\
\text { MNHN IM200717869 } \\
\text { MNHN IM200717904 }\end{array}$ & $\begin{array}{l}\text { Santo } 2006, \mathrm{VM} 53,15^{\circ} 311^{\prime} \mathrm{S}, 167^{\circ} 09^{\prime} \mathrm{E} \text {, intertidal } \\
\text { Panglao } 2004, \mathrm{~S} 21,9^{\circ} 41.70^{\prime} \mathrm{N}, 123^{\circ} 50.90^{\prime} \mathrm{E}, 4-12 \mathrm{~m} \\
\text { Panglao } 2004, \mathrm{~T} 9,9^{\circ} 33.5 \text { 'N, } 123^{\circ} 49.50^{\prime} \mathrm{E}, 97-120 \mathrm{~m}\end{array}$ & $\begin{array}{l}+ \\
- \\
+\end{array}$ \\
\hline Clavatulidae & $\begin{array}{l}\text { Clavatula } \\
\text { Gemmuloborsonia } \\
\text { Perrona } \\
\text { Pusionella } \\
\text { Surcula }\end{array}$ & $\begin{array}{l}\text { xanteni Nolf \& Verstraeten, 2006 } \\
\text { colorata (Sysoev \& Bouchet, 2001) } \\
\text { subspirata (von Martens, 1902) } \\
\text { compacta Strebel, 1914 } \\
\text { nelliae spurius (Hedley, 1922) }\end{array}$ & \begin{tabular}{|l|} 
MNHN IM200717829 \\
MNHN IM200717849 \\
MNHN IM200717833 \\
MNHN IM200717830 \\
NHMUK MOEA 20100552
\end{tabular} & $\begin{array}{c}\text { Angola, AF1, } 8^{\circ} 780^{\prime} \mathrm{S}, 13^{\circ} 230^{\prime} \mathrm{E}, 40-60 \mathrm{~m} \\
\text { EBISCO, DW2619,20060'S, } 160^{\circ} 230^{\prime} \mathrm{E}, 490-550 \mathrm{~m} \\
\text { Angola, AF10, } 15^{\circ} 140^{\prime} \mathrm{S}, 12^{\circ} 290^{\prime} \mathrm{E}, 50 \mathrm{~m} \\
\text { Angola, AF3, } 10^{\circ} 510^{\prime} \mathrm{S}, 14^{\circ} 230^{\prime} \mathrm{E}, 5-10 \mathrm{~m} \\
\text { Off southern Hong Kong, South China Sea }\end{array}$ & $\begin{array}{l}+ \\
+ \\
+ \\
+ \\
+\end{array}$ \\
\hline Cochlespiridae & $\begin{array}{l}\text { Cochlespira } \\
\text { Sibogasyrinx }\end{array}$ & $\begin{array}{l}\text { pulchella (Schepman, 1913) } \\
\text { sp. }\end{array}$ & $\begin{array}{l}\text { MNHN IM200717920 } \\
\text { MNHN IM200717701 }\end{array}$ & 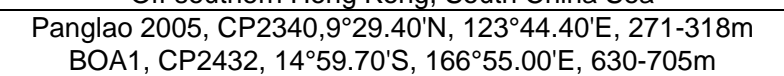 & $\begin{array}{l}+ \\
+\end{array}$ \\
\hline Conidae & $\begin{array}{l}\text { Californiconus } \\
\text { Conasprella } \\
\text { Conus } \\
\text { Profundiconus } \\
\text { Taranteconus }\end{array}$ & $\begin{array}{l}\text { californicus (Hinds, 1844) } \\
\text { pagoda (Kiener, 1845) } \\
\text { consors Sowerby I, 1833 } \\
\text { teramachii (Kuroda, 1956) } \\
\text { chiangi Azuma, 1972 }\end{array}$ & $\begin{array}{l}\text { MNHN IM200717914 } \\
\text { MNHN IM200717939 }\end{array}$ & $\begin{array}{c}\text { Monterey, California } \\
\text { Panglao 2005, CP2380, } 8^{\circ} 41.30^{\prime} \mathrm{N}, 123^{\circ} 17.80^{\prime} \mathrm{E}, 150-163 \mathrm{~m} \\
\text { Santo 2006, AT87,1532.10'S, } 167^{\circ} 16.10^{\circ} \mathrm{E}, 235-271 \mathrm{~m} \\
\text { Philippines } \\
\text { Philippines }\end{array}$ & $\begin{array}{l}\text { Tucker \& Tenorio, } 2009 \\
\text { Tucker \& Tenorio, } 2009 \\
\text { Tucker \& Tenorio, } 2009 \\
\text { Tucker \& Tenorio, } 2009 \\
\text { Tucker \& Tenorio, } 2009\end{array}$ \\
\hline Conorbidae & Benthofascis & Iozoueti Sysoev \& Bouchet, 2001 & MNHN IM200742331 & 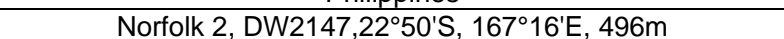 & + \\
\hline Drilliidae & $\begin{array}{l}\text { Agladrillia } \\
\text { Calliclava } \\
\text { Cerodrillia } \\
\text { Clathrodrillia } \\
\text { Clavus } \\
\text { Conopleura } \\
\text { Cruziturricula } \\
\text { Drillia } \\
\text { Fusiturricula } \\
\text { Imaclava } \\
\text { Iredalea } \\
\text { Splendrillia }\end{array}$ & $\begin{array}{c}\text { pudica (Hinds, 1843) } \\
\text { sp. } \\
\text { cybele(Pilsbry \& Lowe, 1932) } \\
\text { walteri (M. Smith, 1946) } \\
\text { canalicularis (Roeding, 1798) } \\
\text { striata Hinds, 1844 } \\
\text { arcuata (Reeve, 1843) } \\
\text { clavata (Sowerby III, 1870) } \\
\text { enae (Bartsch, 1934) } \\
\text { unimaculata (Sowerby I, 1834) } \\
\text { pupoidea (H. Adams, 1872) } \\
\text { sp. }\end{array}$ & \begin{tabular}{l|} 
NHMUK MOEA 20100543 \\
NHMUK MOEA 20100546 \\
NHMUK MOEA 20100548 \\
NHMUK MOEA 20100549 \\
MNHN IM200717858 \\
MNHN IM200717889 \\
NHMUK MOEA 20100541 \\
NHMUK MOEA 20100550 \\
INVEMAR MOL-1929 \\
NHMUK MOEA 20100527 \\
MNHN IM200742556 \\
MNHN IM200717847
\end{tabular} & $\begin{array}{c}\text { Gulf of Panama, JTD-00-51, } 08^{\circ} 36.41^{\prime} \mathrm{N}, 79^{\circ} 09.70^{\prime} \mathrm{W}, 73 \mathrm{~m} \\
\text { Gulf of Panama, JTD-00-47, } 08^{\circ} 31.83^{\prime} \mathrm{N}, 79^{\circ} 05.09^{\prime} \mathrm{W}, 21 \mathrm{~m} \\
\text { Gulf of Panama, JTD-00-18, } 08^{\circ} 19.50^{\prime} \mathrm{N}, 78^{\circ} 47.711^{\prime} \mathrm{W}, 25-32 \mathrm{~m} \\
\text { Gulf of Panama, JTD-00-46, } 08^{\circ} 31.37^{\prime} \mathrm{N}, 79^{\circ} 05.79^{\prime} \mathrm{W}, 24-25 \mathrm{~m} \\
\text { Panglao 2004, S12, } 9^{\circ} 29.40^{\prime} \mathrm{N}, 123^{\circ} 56.00^{\prime} \mathrm{E}, 6-8 \mathrm{~m} \\
\text { Panglao 2004, T41, } 9^{\circ} 29.70^{\prime} \mathrm{N}, 123^{\circ} 50.20^{\prime} \mathrm{E}, 110-112 \mathrm{~m} \\
\text { Gulf of Panama, JTD-00-34, } 08^{\circ} 26.24^{\prime} \mathrm{N}, 79^{\circ} 09.14^{\prime} \mathrm{W}, 66-68 \mathrm{~m} \\
\text { Gulf of Panama, JTD-00-18, } 08^{\circ} 19.50^{\prime} \mathrm{N}, 78^{\circ} 47.71^{\prime} \mathrm{W}, 25-32 \mathrm{~m} \\
\text { Colombia, E-73, } 09^{\circ} 57.53^{\prime} \mathrm{N}, 79^{\circ} 07.71^{\prime} \mathrm{W}, 268-270 \mathrm{~m} \\
\text { Gulf of Panama, JTD-00-46, } 08^{\circ} 31.37^{\prime} \mathrm{N}, 79^{\circ} 05.79^{\prime} \mathrm{W}, 24-25 \mathrm{~m} \\
\text { Santo 2006, DB25, } 15^{\circ} 37.7^{\prime} \mathrm{S}, 167^{\circ} 11.3^{\prime} \mathrm{E}, 10 \mathrm{~m} \\
\text { EBISCO, DW2617, } 20^{\circ} 060^{\prime} \mathrm{S}, 160^{\circ} 220^{\prime} \mathrm{E}, 427-505 \mathrm{~m}\end{array}$ & $\begin{array}{l}\text { McLean, } 1971 \\
\text { McLean, } 1971 \\
\text { McLean, } 1971 \\
- \\
+ \\
- \\
+ \\
\text { McLean, } 1971 \\
\text { - } \\
\text { Shimek, Kohn, } 1981 \\
+ \\
+\end{array}$ \\
\hline Horaiclavidae & $\begin{array}{l}\text { Anacithara } \\
\text { Anguloclavus } \\
\text { Carinapex } \\
\text { Ceritoturris } \\
\text { Horaiclavidae gen. } 1 \\
\text { Horaiclavus } \\
\text { Paradrillia } \\
\end{array}$ & $\begin{array}{l}\text { lita (Mellvill \& Standen, 1896) } \\
\text { sp. } \\
\text { minutissima (Garrett, 1873) } \\
\text { pupiformis (Smith, 1884) } \\
\text { sp. (juvenile) } \\
\text { splendidus (A.Adams, 1867) } \\
\text { sp. (juvenile) }\end{array}$ & \begin{tabular}{l|} 
MNHN IM200742614 \\
MNHN IM200717908 \\
MNHN IM200717868 \\
MNHN IM200717888 \\
MNHN IM200742501 \\
MNHN IM200717840 \\
MNHN IM200742475
\end{tabular} & $\begin{array}{c}\text { Santo 2006, DS99, } 15^{\circ} 32^{\prime} \mathrm{S}, 167^{\circ} 17^{\prime} \mathrm{E}, 100-105 \mathrm{~m} \\
\text { Panglao 2005, CP2332, } 9^{\circ} 38.80^{\prime} \mathrm{N}, 123^{\circ} 45.90^{\prime} \mathrm{E}, 396-418 \mathrm{~m} \\
\text { Panglao 2004, B19, } 9^{\circ} 29.40^{\prime} \mathrm{N}, 123^{\circ} 56.00 ' \mathrm{E}, 17 \mathrm{~m} \\
\text { Panglao 2004, T36, } 9^{\circ} 29.30^{\prime} \mathrm{N}, 123^{\circ} 51.50^{\prime} \mathrm{E}, 95-128 \mathrm{~m} \\
\text { Salomon 2, CP2219, } 7^{\circ} 58^{\prime} \mathrm{S}, 157^{\circ} 34^{\prime} \mathrm{E}, 650-836 \mathrm{~m} \\
\text { EBISCO, DW2631, } 21^{\circ} 030^{\prime} \mathrm{S}, 160^{\circ} 440^{\prime} \mathrm{E}, 372-404 \mathrm{~m} \\
\text { Panglao 2005, CP2396, } 9^{\circ} 36^{\prime} \mathrm{N}, 123^{\circ} 42^{\prime} \mathrm{E}, 609-673 \mathrm{~m}\end{array}$ & $\begin{array}{l}+ \\
+ \\
+ \\
+ \\
+ \\
+ \\
+\end{array}$ \\
\hline Mangeliidae & Anticlinura & sp. & MNHN IM200742513 & Salomon $2, \mathrm{CP} 2182,8^{\circ} 47^{\prime} \mathrm{S}, 159^{\circ} 38^{\prime} \mathrm{E}, 762-1060 \mathrm{~m}$ & + \\
\hline
\end{tabular}




\begin{tabular}{|c|c|c|c|c|c|}
\hline & $\begin{array}{l}\text { Benthomangelia } \\
\text { Eucithara } \\
\text { Heterocithara } \\
\text { Mangeliidae gen. } 1 \\
\text { Mangeliidae gen. } 2 \\
\text { Oenopota } \\
\text { Toxicochlespira }\end{array}$ & $\begin{array}{l}\text { cf. trophonoidea (Schepman, 1913) } \\
\text { cf. coronata (Hinds, 1843) } \\
\text { sp. } \\
\text { sp. } \\
\text { sp. } \\
\text { sp. } \\
\text { pagoda Sysoev \& Kantor, } 1990\end{array}$ & $\begin{array}{l}\text { MNHN IM200717835 } \\
\text { MNHN IM200717900 } \\
\text { MNHN IM200717884 } \\
\text { MNHN IM200717874 } \\
\text { MNHN IM200717872 } \\
\text { MNHN IM200742325 } \\
\text { MNHN IM200717925 }\end{array}$ & $\begin{array}{c}\text { BOA1, CP2462, } 16^{\circ} 37.50^{\prime} \mathrm{S}, 167^{\circ} 57.40^{\prime} \mathrm{E}, 618-641 \mathrm{~m} \\
\text { Panglao 2004, B8, } 9^{\circ} 37.10^{\prime} \mathrm{N}, 123^{\circ} 46.10^{\prime} \mathrm{E}, 3 \mathrm{~m} \\
\text { Panglao 2004, L46, } 9^{\circ} 30.90^{\prime} \mathrm{N}, 123^{\circ} 41.20^{\prime} \mathrm{E}, 90-110 \mathrm{~m} \\
\text { Panglao 2004, T26,943.30'N, } 123^{\circ} 48.80^{\prime} \mathrm{E}, 123-135 \mathrm{~m} \\
\text { Panglao 2004, S26, } 9^{\circ} 41.50^{\prime} \mathrm{N}, 123^{\circ} 51.00^{\prime} \mathrm{E}, 21 \mathrm{~m} \\
\text { Hornsund, Svalbard, 1184-2001, } \\
\text { Salomon 2, CP2227, } 637^{\circ} 20^{\prime} \mathrm{S}, 156^{\circ} 12.70^{\prime} \mathrm{E}, 508-522 \mathrm{~m}\end{array}$ & $\begin{array}{c}+ \\
+ \\
- \\
\text { Radula of Mangelia powisiana } \\
\text { (Dautzenberg, 1887) used } \\
- \\
- \\
+\end{array}$ \\
\hline Mitromorphidae & $\begin{array}{c}\text { Lovellona } \\
\text { Mitromorpha }\end{array}$ & $\begin{array}{c}\text { atramentosa (Reeve, 1849) } \\
\text { metula (Hinds, 1843) }\end{array}$ & $\begin{array}{l}\text { MNHN IM200742552 } \\
\text { MNHN IM200717898 }\end{array}$ & $\begin{array}{l}\text { Santo } 2006, \mathrm{NR} 8,15^{\circ} 35.7^{\prime} \mathrm{S}, 167^{\circ} 07.4^{\prime} \mathrm{E}, 11 \mathrm{~m} \\
\text { Panglao } 2004, \mathrm{~B} 8,9^{\circ} 37.10^{\prime} \mathrm{N}, 123^{\circ} 46.10^{\prime} \mathrm{E}, 3 \mathrm{~m}\end{array}$ & $\begin{array}{l}+ \\
+\end{array}$ \\
\hline Pseudomelatomidae & $\begin{array}{c}\text { Carinodrillia } \\
\text { Cheungbeia } \\
\text { Comitas } \\
\text { Crassispira } \\
\text { Funa } \\
\text { Hindsiclava } \\
\text { Inquisitor } \\
\text { Knefastia } \\
\text { Leucosyrinx } \\
\text { Otitoma } \\
\text { Pilsbryspira } \\
\text { Pseudomelatoma } \\
\text { Ptychobela } \\
\text { Pyrgospira } \\
\text { Tiariturris } \\
\text { Zonulispira }\end{array}$ & $\begin{array}{c}\text { dichroaPilsbry \& Lowe, 1932 } \\
\text { robusta (Hinds, 1839) } \\
\text { sp. } \\
\text { quadrilirata (E.A.Smith, 1882) } \\
\text { incerta (Smith, 1877) } \\
\text { alesidota (Dall, 1889) } \\
\text { sp. } \\
\text { tuberculifera (Broderip \& Sowerby, } \\
\text { 1829) } \\
\text { sp. } \\
\text { sp. } \\
\text { jayana (C. B. Adams, 1850) } \\
\text { moesta (Carpenter, 1865) } \\
\text { suturalis (Gray, 1838) } \\
\text { aenone (Dall, 1919) } \\
\text { spectabilis Berry, 1958 } \\
\text { sp. }\end{array}$ & $\begin{array}{c}\text { NHMUK MOEA } 20100530 \\
\text { NHMUK MOEA } 20100556 \\
\text { MNHN IM200717918 } \\
\text { MNHN IM200717755 } \\
\text { NHMUK MOEA } 20100533 \\
\text { NHMUK MOEA } 20100525 \\
\text { MNHN IM200717851 } \\
\text { NHMUK MOEA } 20100533 \\
\text { MNHN IM200717846 } \\
\text { MNHN IM200717905 } \\
\text { USNM } 857830 \\
\text { NHMUK MOEA } 20100560 \\
\text { NHMUK MOEA } 20100539 \\
\text { NHMUK MOEA } 20100540 \\
\text { NHMUK MOEA } 20100536\end{array}$ & $\begin{array}{c}\text { Gulf of Panama, JTD-00-18, } 08^{\circ} 19.50^{\prime} \mathrm{N}, 78^{\circ} 47.71^{\prime} \mathrm{W}, 25-32 \mathrm{~m} \\
\text { Off southern Hong Kong, South China Sea, Sta. 70 } \\
\text { Panglao 2005, CP2388, } 9^{\circ} 26.90^{\prime} \mathrm{N}, 123^{\circ} 34.50^{\prime} \mathrm{E}, 762-786 \mathrm{~m} \\
\text { Panglao 2004, L46, } 9^{\circ} 30.90^{\prime} \mathrm{N}, 123^{\circ} 41.20^{\prime} \mathrm{E}, 90-110 \mathrm{~m} \\
\text { Off southern Hong Kong, South China Sea, Sta. 70 } \\
\text { Lower Florida Keys, JTD-01-15, } 24^{\circ} 33.47^{\prime} \mathrm{N}, 81^{\circ} 07.72^{\prime} \mathrm{W}, 117- \\
148 \mathrm{~m} \\
\text { EBISCO, DW2625, } 20^{\circ} 050^{\prime} \mathrm{S}, 160^{\circ} 190^{\prime} \mathrm{E}, 627-741 \mathrm{~m} \\
\text { Gulf of Panama, JTD-00-18, } 08^{\circ} 19.50^{\prime} \mathrm{N}, 78^{\circ} 47.71^{\prime} \mathrm{W}, 25-32 \mathrm{~m} \\
\text { EBISCO, CP2600, } 19^{\circ} 380^{\prime} \mathrm{S}, 158^{\circ} 460^{\prime} \mathrm{E}, 603-630 \mathrm{~m} \\
\text { Panglao 2005, CP2348, } 9^{\circ} 29.60^{\prime} \mathrm{N}, 123^{\circ} 52.50^{\prime} \mathrm{E}, 196-216 \mathrm{~m} \\
\text { Carrie Bow Cay, Belize, intertidal } \\
\text { California } \\
\text { Luong SoN, } 15 \mathrm{~km} \text { N. Nha Trang, Vietnam } \\
\text { Gulf of Panama, JTD-00-18, } 08^{\circ} 19.50^{\prime} \mathrm{N}, 78^{\circ} 47.71^{\prime} \mathrm{W}, 25-32 \mathrm{~m} \\
\text { Gulf of Panama, JTD-00-34, } 08^{\circ} 26.24^{\prime} \mathrm{N}, 7909.14^{\prime} \mathrm{W}, 66-68 \mathrm{~m} \\
\text { Gulf of Panama, JTD } 08^{\circ} 19.50^{\prime} \mathrm{N}, 78^{\circ} 47.71^{\prime} \mathrm{W}, 25-32 \mathrm{~m}\end{array}$ & $\begin{array}{l}+ \\
+ \\
+ \\
+ \\
+ \\
+ \\
+ \\
+ \\
+ \\
+ \\
+ \\
+ \\
\text { Kantor, } \\
+ \\
+ \\
+ \\
+ \\
+\end{array}$ \\
\hline Raphitomidae & $\begin{array}{c}\text { Daphnella } \\
\text { Eucyclotoma } \\
\text { Glyphostomoides } \\
\text { (cf.) } \\
\text { Gymnobela } \\
\text { Hemilienardia } \\
\text { Kermia } \\
\text { Pleurotomella } \\
\text { Raphitoma } \\
\text { Rimosodaphnella } \\
\text { Taranis } \\
\text { Teretiopsis } \\
\text { Thatcheria } \\
\text { Tritonoturris (cf.) } \\
\text { Veprecula }\end{array}$ & $\begin{array}{c}\text { sp. } \\
\text { cymatodes (Hervier, 1899) } \\
\text { sp. } \\
\text { sp. } \\
\text { calcicincta (Melvill \& Standen, 1895) } \\
\text { aureotincta (Hervier, 1897) } \\
\text { sp. } \\
\text { rubroapicata (E. A. Smith, 1885) } \\
\text { sp. } \\
\text { sp. } \\
\text { cf. hyalina Sysoev \& Bouchet, 2001 } \\
\text { mirabilis (Angas, 1877) } \\
\text { sp. } \\
\text { sp. }\end{array}$ & $\begin{array}{l}\text { MNHN IM200717927 } \\
\text { MNHN IM200717903 } \\
\text { MNHN IM200717892 } \\
\text { MNHN IM200717841 } \\
\text { MNHN IM200717861 } \\
\text { MNHN IM200717878 } \\
\text { MNHN IM200717848 } \\
\text { MNHN IM200717890 } \\
\text { MNHN IM200717836 } \\
\text { MNHN IM200742296 } \\
\text { MNHN IM200717845 } \\
\text { MNHN IM200717924 } \\
\text { MNHN IM200717891 } \\
\text { MNHN IM200717883 }\end{array}$ & 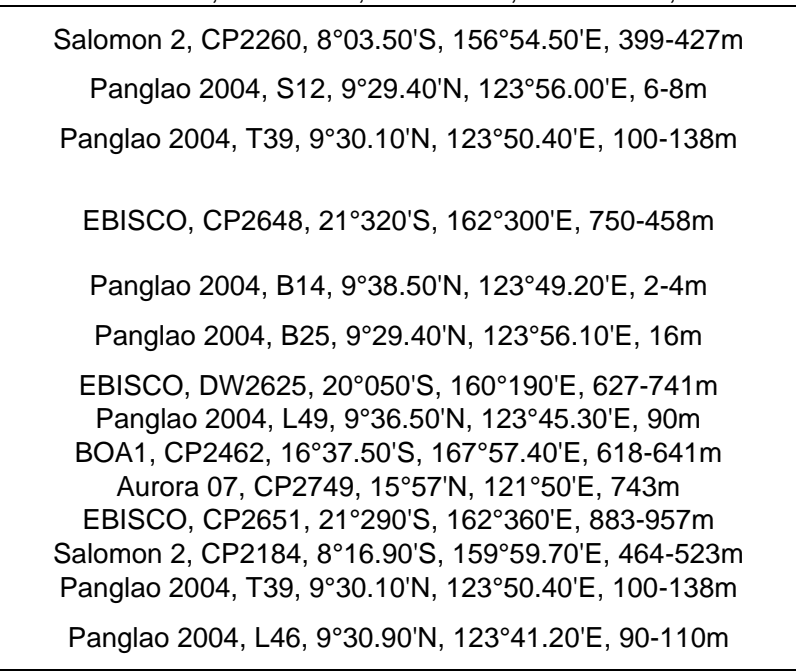 & $\begin{array}{c}\text { Radula of Daphnella mitrellaformis } \\
\text { (Nomura, 1940) used } \\
- \\
- \\
\text { radula of Gymnobela yoshidai } \\
\text { (Kuroda et Habe in Habe, 1962) } \\
\text { used } \\
- \\
\text { radula of Kermia irretita (Hedley, } \\
\text { 1899) used } \\
- \\
\text { radula of Raphitoma sp. used } \\
- \\
\text { Radula-less species } \\
\text { Radula-less species } \\
\text { Kantor, Taylor, 2002 } \\
- \\
\text { radula of Veprecula vepratica } \\
\text { (Hedley, 1903) used }\end{array}$ \\
\hline Terebridae & Cinguloterebra & cf. fenestrata (Hinds, 1844) & MNHN IM200716735 & 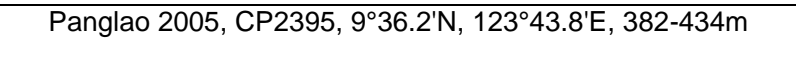 & + \\
\hline
\end{tabular}




\begin{tabular}{|c|c|c|c|c|c|}
\hline & $\begin{array}{l}\text { Clathroterebra } \\
\text { Euterebra } \\
\text { Hastula } \\
\text { Hastulopsis } \\
\text { Myurella } \\
\text { Oxymeris } \\
\text { Strioterebrum } \\
\text { Terebra } \\
\text { Terenolla }\end{array}$ & $\begin{array}{c}\text { fortunei (Deshayes, 1857) } \\
\text { tristis (Deshayes, 1859) } \\
\text { strigilata (Linnaeus, 1758) } \\
\text { amoena (Deshayes, 1859) } \\
\text { kilburni (Burch, 1965) } \\
\text { maculatus (Linnaeus, 1758) } \\
\text { plumbea (Quoy \& Gaimard, 1833) } \\
\text { textilis Hinds, 1844 } \\
\text { pygmaea (Hinds, 1844) }\end{array}$ & $\begin{array}{l}\text { MNHN IM200730401 } \\
\text { MNZ } \\
\text { MNHN IM200730420 } \\
\text { MNHN IM200730480 } \\
\text { MNHN IM200730459 } \\
\text { MNHN IM200730371 } \\
\text { MNHN IM200730558 } \\
\text { MNHN IM200717938 } \\
\text { MNHN IM200730449 }\end{array}$ & $\begin{array}{c}\text { Panglao 2005, CP2331, } 9^{\circ} 39.2^{\prime} \mathrm{N}, 123^{\circ} 47.5^{\prime} \mathrm{E}, 255-268 \mathrm{~m} \\
\text { New-Zealand } \\
\text { Santo 2006, VM24, } 15^{\circ} 35.2^{\prime} \mathrm{S}, 167^{\circ} 59.4^{\prime} \mathrm{E} \text {, intertidal } \\
\text { Santo 2006, FR10, } 15^{\circ} 36.9^{\prime} \mathrm{S}, 167^{\circ} 10.5^{\prime} \mathrm{E}, 6-33 \mathrm{~m} \\
\text { Panglao 2004, S18, } 9^{\circ} 35.7^{\prime} \mathrm{N}, 123^{\circ} 44.4^{\prime} \mathrm{E}, 0-2 \mathrm{~m} \\
\text { Santo 2006, NR5, } 15^{\circ} 28.7^{\prime} \mathrm{S}, 167^{\circ} 15.2^{\prime} \mathrm{E}, 19 \mathrm{~m} \\
\text { Santo 2006, ED5, } 15^{\circ} 31^{\prime} \mathrm{S}, 167^{\circ} 09^{\prime} \mathrm{E}, \text { intertidal } \\
\text { Santo 2006, LD28, } 15^{\circ} 35.40^{\prime} \mathrm{S}, 166^{\circ} 58.70^{\prime} \mathrm{E}, 3-8 \mathrm{~m} \\
\text { Panglao 2004, S2, } 9^{\circ} 37.4^{\prime} \mathrm{N}, 123^{\circ} 54.5^{\prime} \mathrm{E}, 4-5 \mathrm{~m}\end{array}$ & $\begin{array}{l}\text { Radula-less species } \\
\quad \text { Rudman, } 1969 \\
\quad- \\
\text { Radula-less species } \\
\text { Radula-less species } \\
\text { Radula-less species } \\
\text { Radula-less species } \\
\text { Radula-less species } \\
\text { Radula-less species }\end{array}$ \\
\hline Turridae & $\begin{array}{l}\text { Gemmula } \\
\text { Iotyrris } \\
\text { Lophiotoma } \\
\text { Lucerapex } \\
\text { Polystira } \\
\text { Ptychosyrinx } \\
\text { Turridrupa } \\
\text { Turris } \\
\text { Xenuroturris } \\
\end{array}$ & $\begin{array}{l}\text { rarimaculata Kuroda \& Oyama, } 1971 \\
\text { cingulifera (Lamarck, 1822) } \\
\text { acuta (Perry, 1811) } \\
\text { cf. casearia (Hedley \& Petterd, 1906) } \\
\text { albida (Perry, 1811) } \\
\text { carynae (Haas, 1949) } \\
\text { cf. armillata (Reeve, 1845) } \\
\text { babylonia Linnaeus, 1758 } \\
\text { legitima Iredale, 1929 } \\
\end{array}$ & $\begin{array}{c}\text { MNHN IM200717838 } \\
\text { MNHN IM200717685 } \\
\text { MNHN IM200717860 } \\
\text { MNHN IM200742448 } \\
\text { NHMUK MOEA } \\
20110066 \\
\text { USNM } 832922 \\
\text { MNHN IM200717850 } \\
\text { MNHN IM200717754 } \\
\text { MNHN IM200717684 } \\
\end{array}$ & $\begin{array}{c}\text { EBISCO, DW2533, } 22^{\circ} 180^{\prime} \mathrm{S}, 159^{\circ} 280^{\prime} \mathrm{E}, 360-370 \mathrm{~m} \\
\text { Santo 2006, FS84, } 15^{\circ} 33.6^{\prime} \mathrm{S}, 167^{\circ} 16.6^{\prime}, 8-9 \mathrm{~m} \\
\text { Panglao 2004, R44, } 9^{\circ} 33.30^{\prime} \mathrm{N}, 123^{\circ} 43.90^{\prime} \mathrm{E}, 2 \mathrm{~m} \\
\text { Panglao 2005, CP2363, } 9^{\circ} 06^{\prime} \mathrm{N}, 123^{\circ} 25^{\prime} \mathrm{E}, 437-439 \mathrm{~m} \\
\text { S. of Bahia Honda Key, Florida Keys, } 24834.24^{\prime} \mathrm{N} ; 81816.64^{\prime} \mathrm{W} \text {, } \\
30 \mathrm{~m} \\
\text { North Atlantic, } 38^{\circ} 0.14^{\prime} \mathrm{N}, 70^{\circ} 29.28^{\prime} \mathrm{W}, 3188-5300 \mathrm{~m} \\
\text { EBISCO, DW2607, } 19^{\circ} 330^{\prime} \mathrm{S}, 158^{\circ} 400^{\prime} \mathrm{E}, 400-413 \mathrm{~m} \\
\text { Panglao 2004, R42, } 9^{\circ} 37.10^{\prime} \mathrm{N}, 123^{\circ} 52.60^{\prime} \mathrm{E}, 8-22 \mathrm{~m} \\
\text { Santo 2006, DR87, } 15^{\circ} 38.5^{\prime} \mathrm{S}, 167^{\circ} 15.1^{\prime} \mathrm{E}, 13 \mathrm{~m} \\
\end{array}$ & $\begin{array}{c}+ \\
+ \\
+ \\
+ \\
\text { Bandel, } 1984 \\
- \\
- \\
\text { A.E. Fedosov, unpublished } \\
+ \\
\end{array}$ \\
\hline Outgroups & $\begin{array}{l}\text { Belomitra } \\
\text { Harpa } \\
\text { Laevistrombus } \\
\text { Turrilatirus } \\
\text { Vexillum } \\
\text { Xenophora } \\
\end{array}$ & $\begin{array}{c}\text { sp. } \\
\text { kajiyamai Habe et Kosuge, } 1970 \\
\text { guidoi (Man in't Veld \& De Turck, 1998) } \\
\text { turritus (Gmelin , 1791) } \\
\text { costatum (Gmelin, 1791) } \\
\text { solarioides (Reeve, 1845) } \\
\end{array}$ & $\begin{array}{l}\text { MNHN IM200911057 } \\
\text { MNHN IM200740569 } \\
\text { MNHN IM200911060 } \\
\text { MNHN IM200911059 } \\
\text { MNHN IM200911058 } \\
\text { MNHN IM200911061 } \\
\end{array}$ & 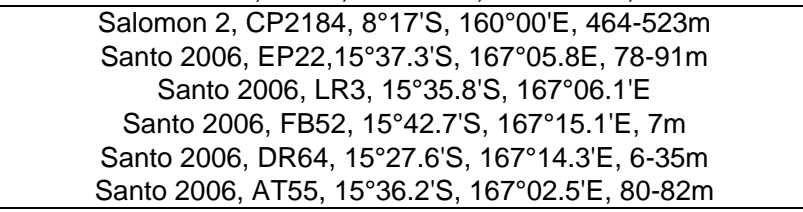 & $\begin{array}{c}++ \\
\text { Hughes \& Emerson, } 1987 \\
\text { Bandel, } 1984 \\
\text { Radula of Latirus sp. used } \\
+ \\
\text { Bandel, } 1984 \\
\end{array}$ \\
\hline
\end{tabular}




\section{Figure captions}

Figs. 1-4. Diagrammatic sections through the anterior foregut of Conoidea. 1. Anterior foregut of the Conoidea with non-hypodermic marginal radular teeth and odontophore (generalized representative of the clade B). A duplex marginal tooth detached from the subradular membrane is used at the proboscis tip for stabbing and envenomating the prey. 2. Section of the tip of the proboscis with the duplex marginal tooth held by sphincters of the buccal tube (actual specimen of Aforia kupriyanovi Sysoev \& Kantor, 1988 - Cochlespiridae). 3. Anterior foregut of the Conoidea with hypodermic marginal radular teeth and lacking odontophore (generalized representative of clade $A$ ). A hypodermic marginal tooth detached from the subradular membrane is used at the proboscis tip. 4. Section of the tip of the proboscis with the hypodermic marginal tooth held by a sphincter of the buccal tube (actual specimen of Phymorhynchus wareni Sysoev \& Kantor, 1995 - Raphitomidae).

Abbreviations: bts - buccal tube sphincter; dmt - duplex marginal tooth at the proboscis tip; hmt - hypodermic marginal tooth at the proboscis tip; mb - muscular bulb of the venom gland; oe - oesophagus; pr - proboscis; rhs - rhynchostomal sphincter; rs - radular sac without odontophore; rsod - radular sac with odontophore; vg - venom gland.

Fig. 5. Evolution of the central radular tooth morphology (character 1) mapped on the conoidean molecular phylogeny (Puillandre et al., 2011). Character states are treated as unordered. The different shading and tiling of the branches corresponds to the most parsimonious ancestral state for the corresponding clade. The mixed shading and/or tiling of the branch indicates that analysis was not able to resolve the single most parsimonious state.

Fig. 6. Evolution of the central radular tooth morphology mapped on the conoidean molecular phylogeny (character 1). A stepmatrix parsimony model was used, interdicting reversion of the character states. Since central teeth are absent in the entire clade A, only clade B is illustrated.

Figs. 7-13. Radulae of Drilliidae. If not otherwise mentioned, data for the specimens are given in Table 2. 7-8. Splendrillia sp., MNHN IM200717847. 9. Clavus exasperatus (Reeve, 1843), MNHN, New-Caledonia, LIFOU 2000, st. 1420, 2047.7'S, $167^{\circ} 09.35^{\prime} E, 4-5 \mathrm{~m}$. 10. Imaclava pilsbryi (Bartsch, 1950), after Kantor and Taylor, 2000. 11. Cruziturricula arcuata (Reeve, 1843), NHMUK MOEA 20100541. Semi-enrolled marginal teeth. 12-13. Clavus sp. 3, MNHN uncataloged, BATHUS 2, DW714; 12 - bending plane of the 
radula, arrows indicate strong wear of the teeth; 13 - central part of the same radula, showing intact central and lateral teeth.

Abbreviations: ct - central tooth; It - lateral tooth, $\mathrm{mt}$ - marginal tooth.

Figs. 14-26. Radulae of Pseudomelatomidae. If not otherwise mentioned, data for the specimens are given in Table 2. 14. Tiariturris spectabilis Berry, 1958, NHMUK MOEA 20100540. Radula with solid recurved marginal teeth and broad central teeth. 15. Comitas onokeana vivens Dell, 1956, MNHN, New-Caledonia, MONTROUZIER, st. 1269, after Kantor and Taylor, 2000. Radula with paired plate-like lateral teeth. 1617.Comitas sp., MNHN IM200717918. 17 - enlarged central segment of the radula. 18. Knefastia tuberculifera (Broderip \& Sowerby, 1829), NHMUK MOEA 20100533. Enlarged central segment of the radula. 19-20. Crassiclava turricula (Sowerby, 1834). Costa Rica, Off Nacascola, West side of Bahia Culebra, after Kantor et al., 1997. Radula with paired plate-like lateral teeth. 21. Zonulispira sp., NHMUK MOEA 20100536. Radula with semi-enrolled marginal teeth. 22. Ptychobela suturalis (Gray, 1838), NHMUK MOEA 20100560. Radula with semi-enrolled marginal teeth. 23-26. Diagrammatic transverse sections of different duplex marginal teeth. Black horizontal line represents the subradular membrane. 23 - Comitas-type; 24 - typical duplex tooth; 25 - semienrolled tooth of Zonulispira; 26 - semienrolled tooth of Ptychobela.

Abbreviations: al - accessory limb; ct - central tooth; It - lateral tooth; $\mathrm{ml}$ - major limb; vlt vestigial lateral tooth.

Fig. 27. Evolution of the lateral radular tooth morphology (character 2) mapped on the conoidean molecular phylogeny (Puillandre et al., 2011). A stepmatrix parsimony model was used, interdicting reversion of the character states.

Figs. 28-33. Radulae of Clavatulidae. If not otherwise mentioned, data for the specimens are given in Table 2. 28-29. Pusionella compacta Strebel, 1914, MNHN IM200717830. 29 enlarged central segment of the radula with vestigial lateral teeth. 30-31. Clavatula xanteni Nolf \& Verstraeten, 2006, MNHN IM200717829. 31 - enlarged central segment of the radula. Arrow indicates the narrow central tooth. 32. Toxiclionella tumida (Sowerby, 1870), South Africa, after Kantor, Taylor (2000). Semi-enrolled marginal teeth. Left upper corner - diagrammatic section of the tooth. 33. Gemmuloborsonia colorata (Sysoev \& Bouchet, 2001), MNHN IM200717849.

Abbreviations: vlt - vestigial lateral teeth; ct - central tooth.

Figs. 34-42. Radulae of Turridae (34-35), Pseudomelatomidae (36-39), and Cochlespiridae (40-42) with different duplex marginal teeth. If not otherwise mentioned, data for the 
specimens are given in Table 2. 34. Xenuroturris legitima Iredale, 1929, MNHN IM200717684. 35. Turridrupa acutigemmata (E. A. Smith, 1877), MNHN uncataloged, New Caledonia. Radula with narrow central and plate-like lateral teeth. 36. Carinodrillia dichroa Pilsbry \& Lowe, 1932, NHMUK MOEA 20100530. 37. Funa incerta (Smith, 1877), NHMUK MOEA 20100554. 38. Cheungbeia robusta (Hinds, 1839), NHMUK MOEA 20100557. 39. Inquisitor sp., MNHN IM200717851. 40-41. Cochlespira radiata (Dall, 1889), MNHN, SE Brazil, after Kantor and Taylor, 2000. 42. Sibogasyrinx sp., MNHN IM200717701.

Abbreviations: al - accessory limb of the marginal duplex tooth; ct - central tooth; It -lateral tooth; $\mathrm{ml}$ - major limb of the marginal duplex tooth.

Fig. 43. Evolution of marginal tooth morphology (character 3) mapped on the conoidean molecular phylogeny (Puillandre et al., 2011). Character states are treated as unordered.

Fig. 44. Evolutionary transformations of duplex marginal tooth morphology (character 4) mapped on the conoidean molecular phylogeny (Puillandre et al., 2011). Character states are treated as unordered. Since duplex marginal teeth are absent in the entire clade A, only clade B is illustrated.

Fig. 45. Presence or absence of a spur on marginal teeth (character 5) mapped on the conoidean molecular phylogeny (Puillandre et al., 2011). Character states are treated as unordered. The spur is absent in most of clade $B$, except some Terebridae. Therefore for clarity only Terebridae from clade B are shown.

Figs. 46-53. Radula of Terebridae (46-49) and various hypodermic teeth from species of clade $A$ (50-53). If not otherwise mentioned, data for the specimens are given in Table 2. 46. Pellifronia jungi (Lai, 2001), MNHN 30591, Salomon 2, CP2195. 47.

Cinguloterebra cf. fenestrata Hinds, 1844, MNHN 30565, Panglao 05, st. CP2340. 48. Duplicaria bernardi (Deshayes, 1857), Venus Bank, off NE end of Moreton Island, Moreton Bay, Queensland, Australia, $27^{\circ 02}$ '069" S, 15319'00" E, 3.5-4.8 m, leg. Glover, Taylor, 2008. 49. Impages hectica (Linnaeus, 1758), MNHN, uncataloged, Philippines, Panglao Island, Alona Beach, intertidal, 2004. 50. Mangelia powisiana (Dautzenberg, 1887). Plymouth, England, after Taylor et al. (1993). 51. Bathytoma neocaledonica Puillandre et al., 2010, MNHN IM200717857. 52. Genota mitriformis (Wood, 1828), MNHN IM200742293. 53. Benthomangelia trophonoidea (Schepman, 1913), MNHN IM200717835. 
Fig. 54. Presence or absence of barbs on marginal teeth (character 6) mapped on the conoidean molecular phylogeny (Puillandre et al., 2011). Character states are treated as unordered. The barb(s) are present only in clade A and therefore clade B is omitted.

Fig. 55. Presence or absence of blade on marginal teeth (character 7) mapped on the conoidean molecular phylogeny (Puillandre et al., 2011). Character states are treated as unordered. The blade is absent in most of clade B, except some Terebridae. Therefore for clarity only Terebridae from clade B are shown.

Fig. 56. Presence or absence of ligament of marginal teeth (character 8) mapped on the conoidean molecular phylogeny (Puillandre et al., 2011). Character states are treated as unordered. The ligament is present only in clade A and therefore clade B is omitted.

Fig. 57. Presence or absence of use of the separate marginal teeth on the proboscis tip (character 9) mapped on the conoidean molecular phylogeny (Puillandre et al., 2011). Character states are treated as unordered

Fig. 58-63. Radula of Gemmula Weinkauff, 1875, demonstrating different degree of fusion of central and lateral teeth and the appearance of the "central formation". 58-59. Gemmula unilineata Powell, 1967, MNHN uncataloged, NORFOLK 2, New Caledonia, sta. DW 2097, bank Kaimon Maru, 2444'S, 16806'E, 580-583 m. 60-61. Gemmula rarimaculata Kuroda et Oyama in Kuroda et al., 1971, MNHN uncataloged, MUSORSTOM 5, Coral

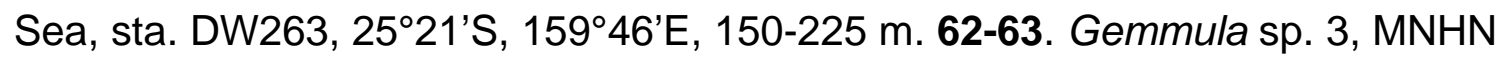
uncataloged, MUSORSTOM 10, Fiji, sta. CP1354, 17²4.6'S, 17855.0'E, 959-963 m. 


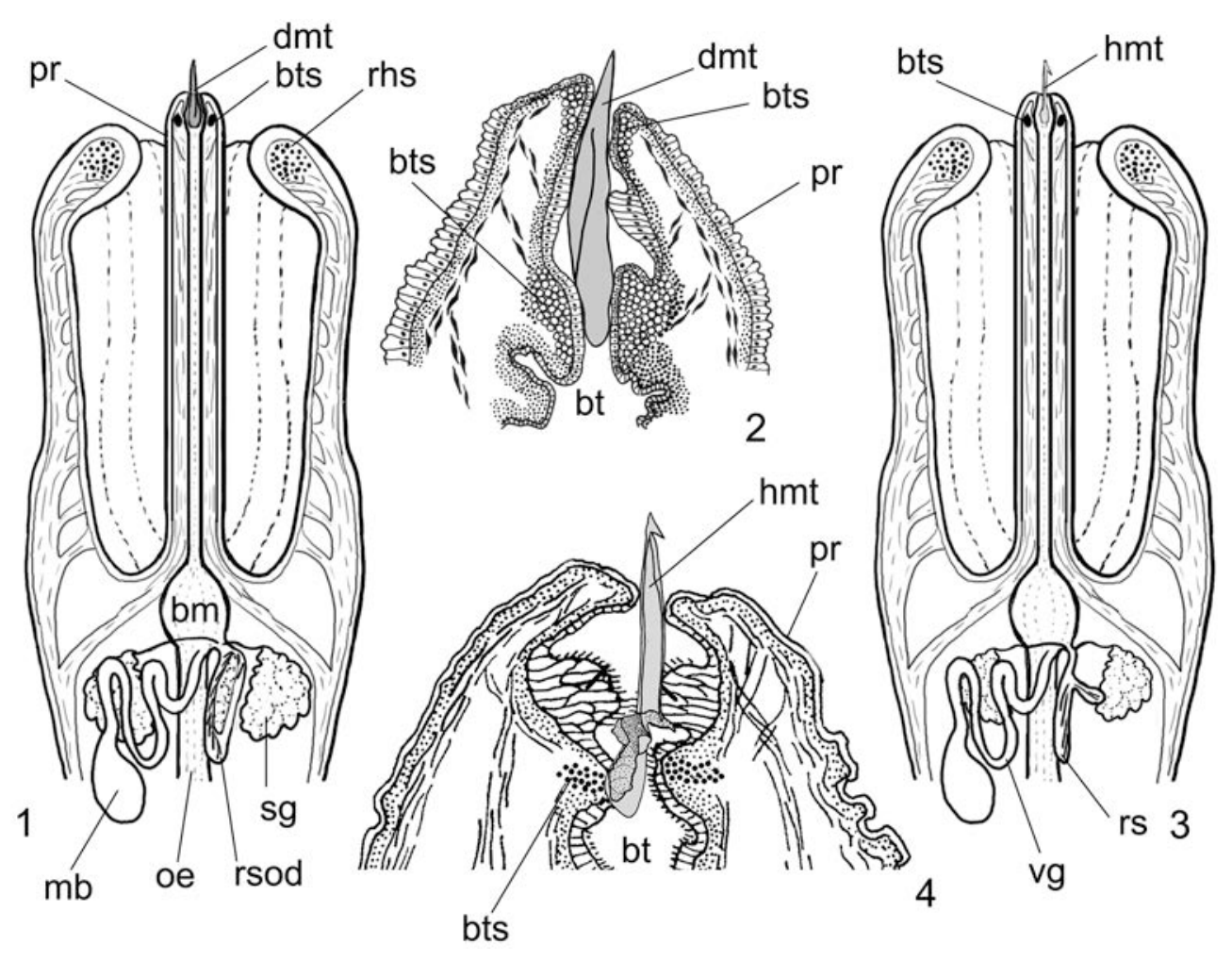




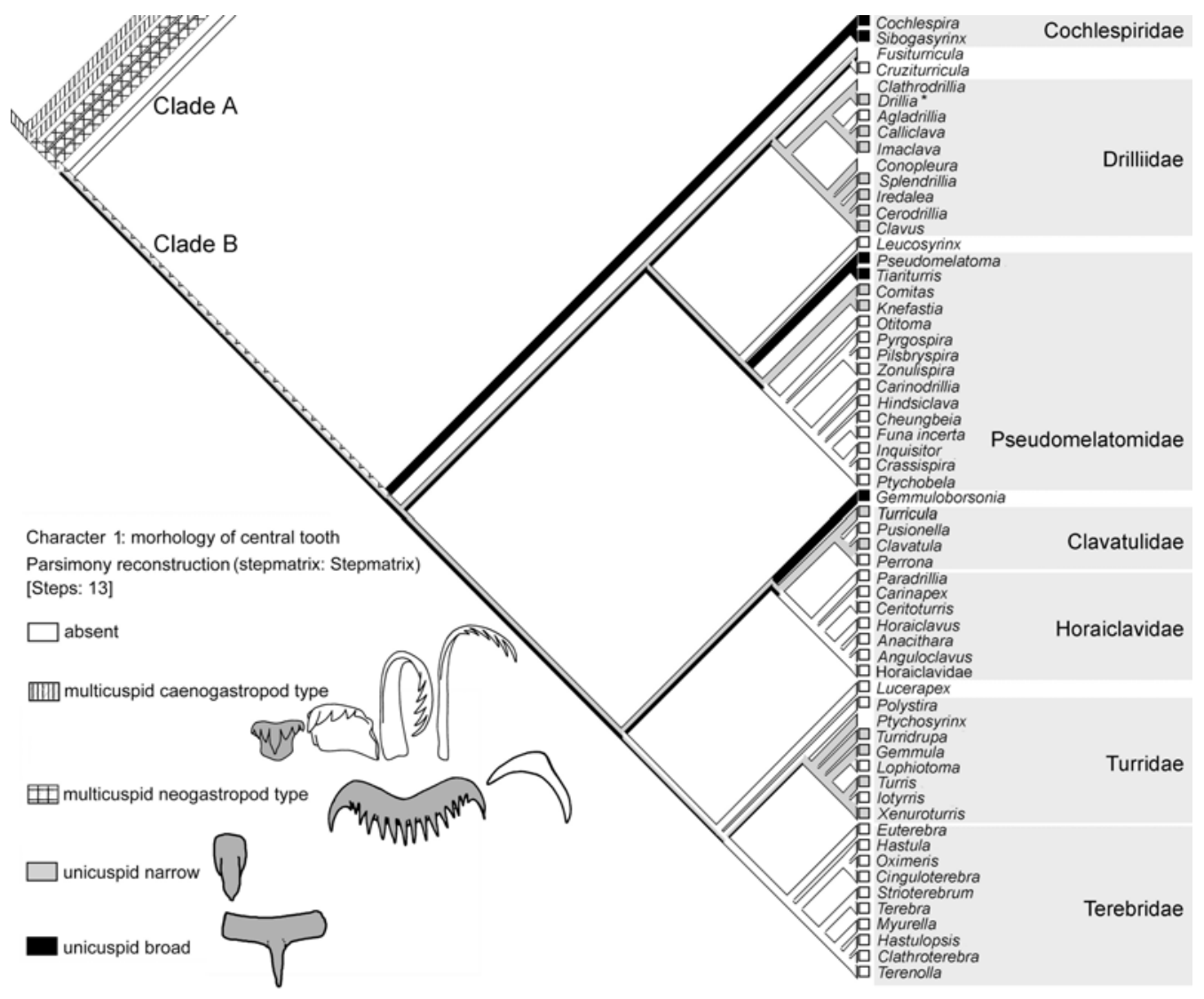

Fig 5 


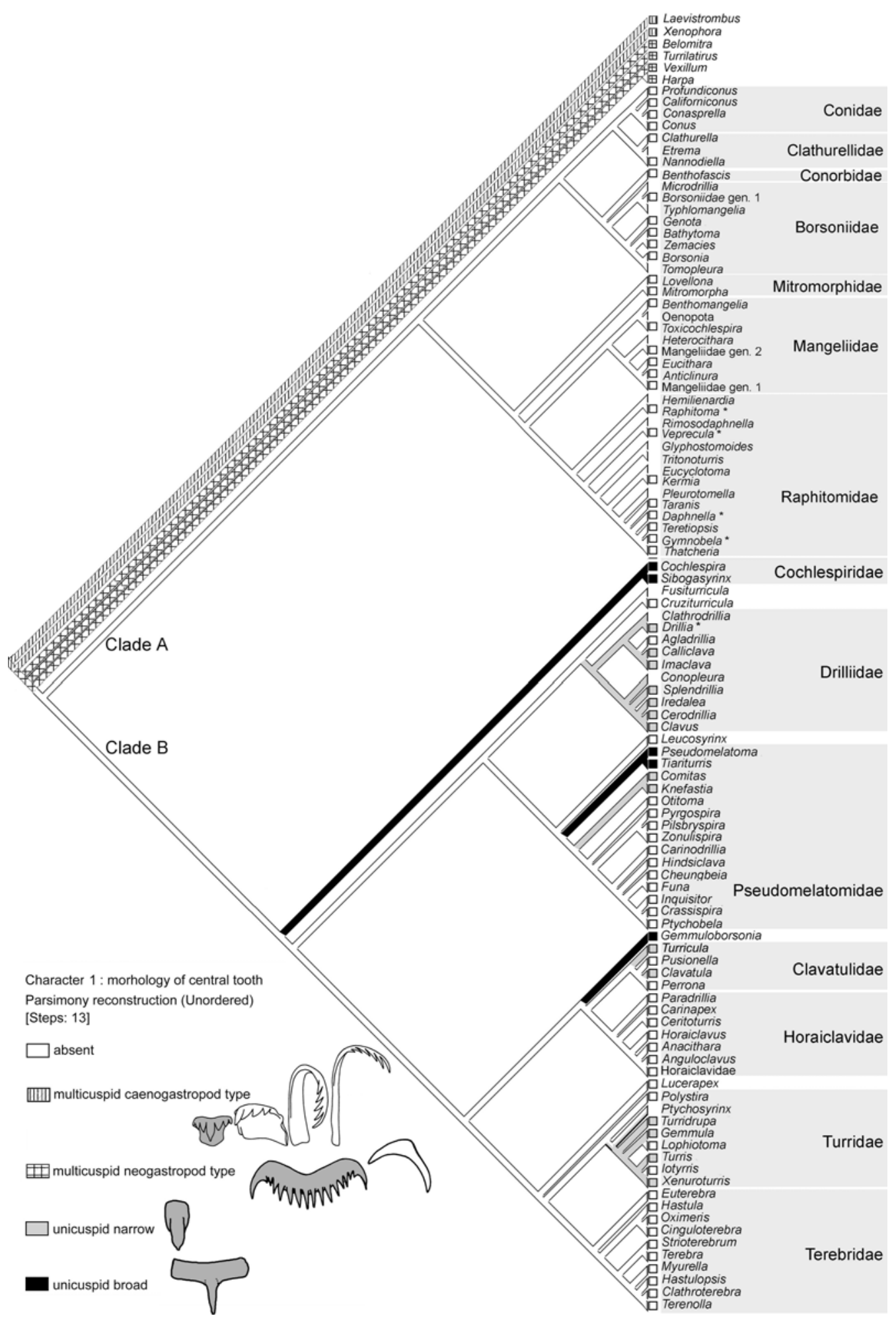



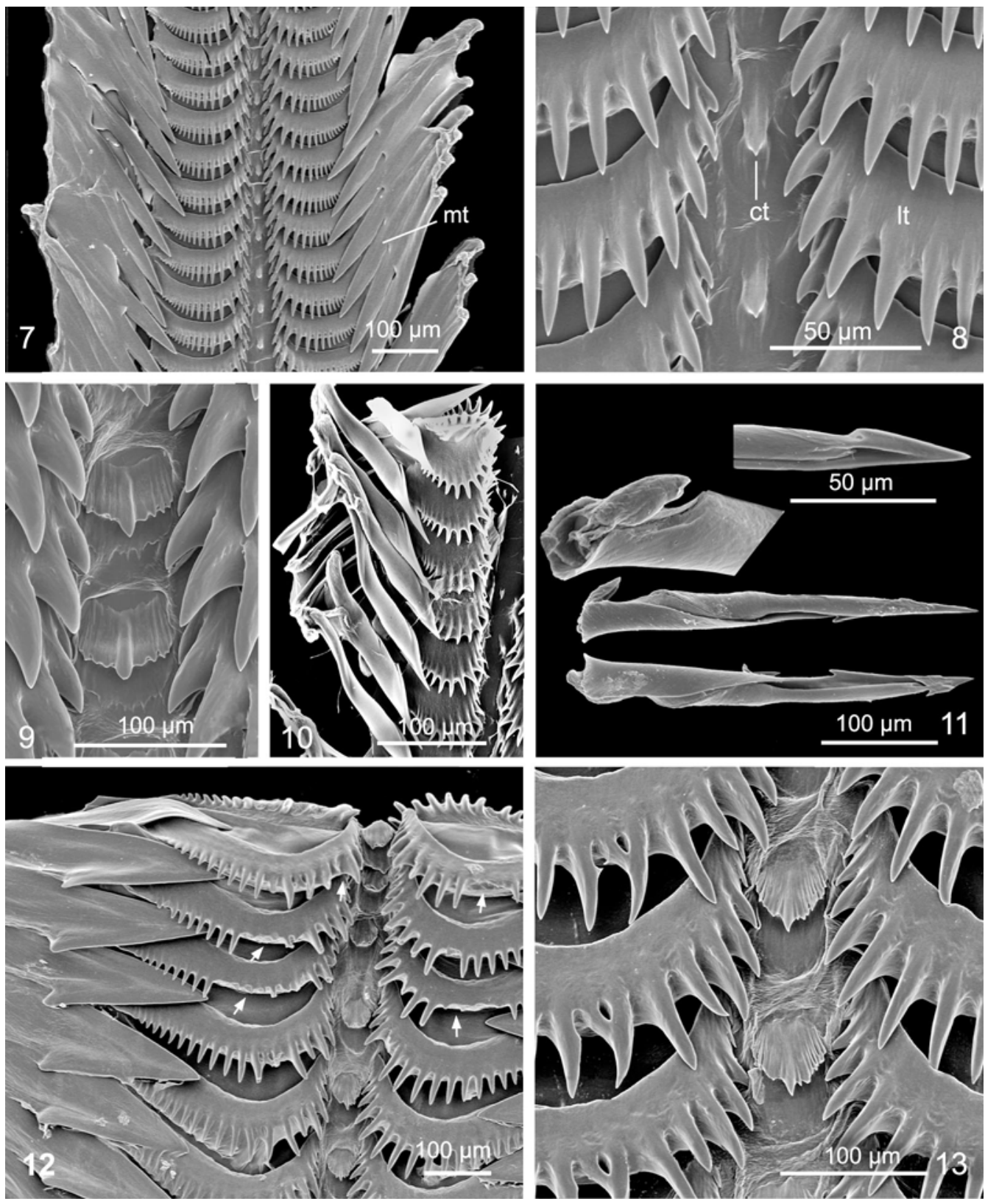

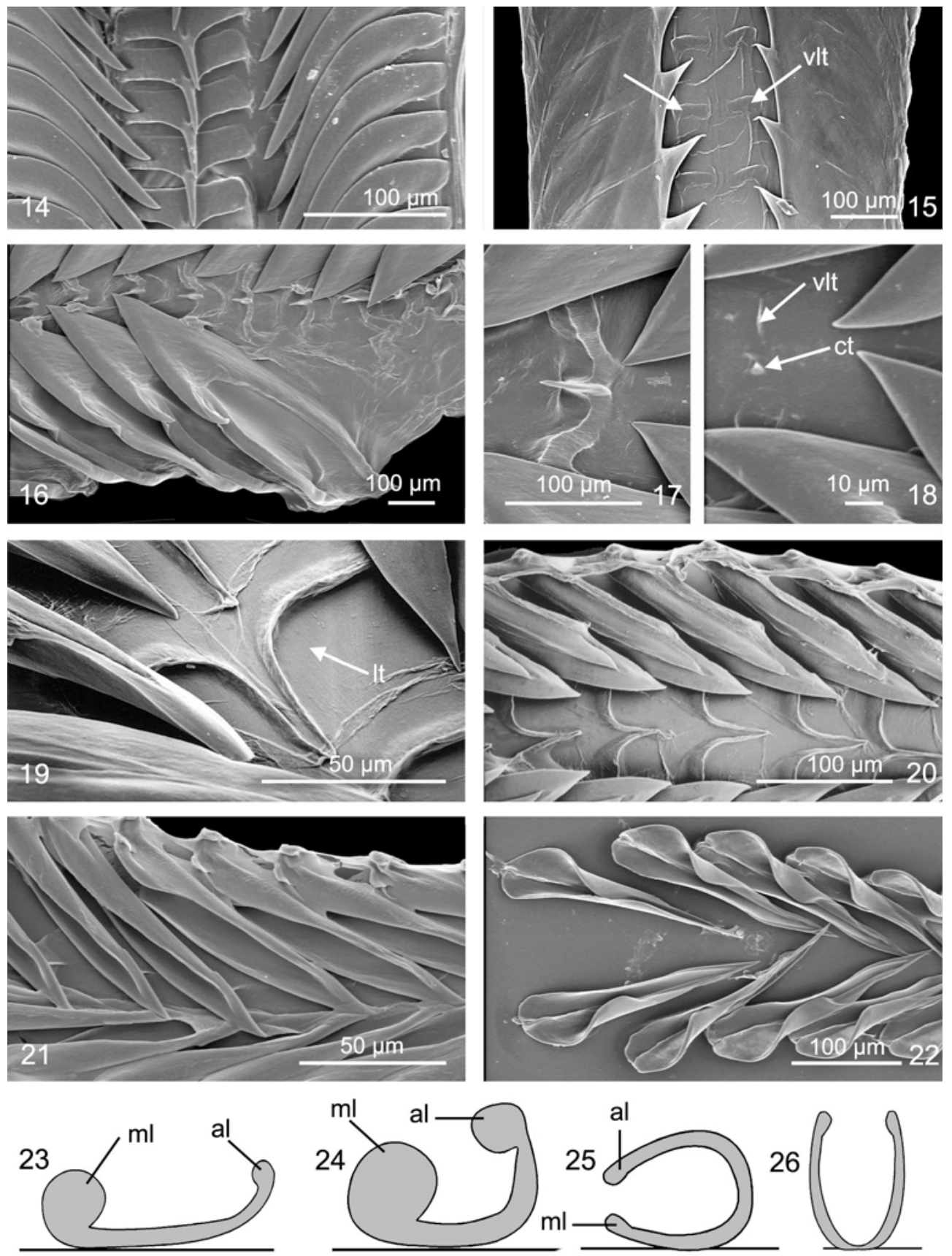


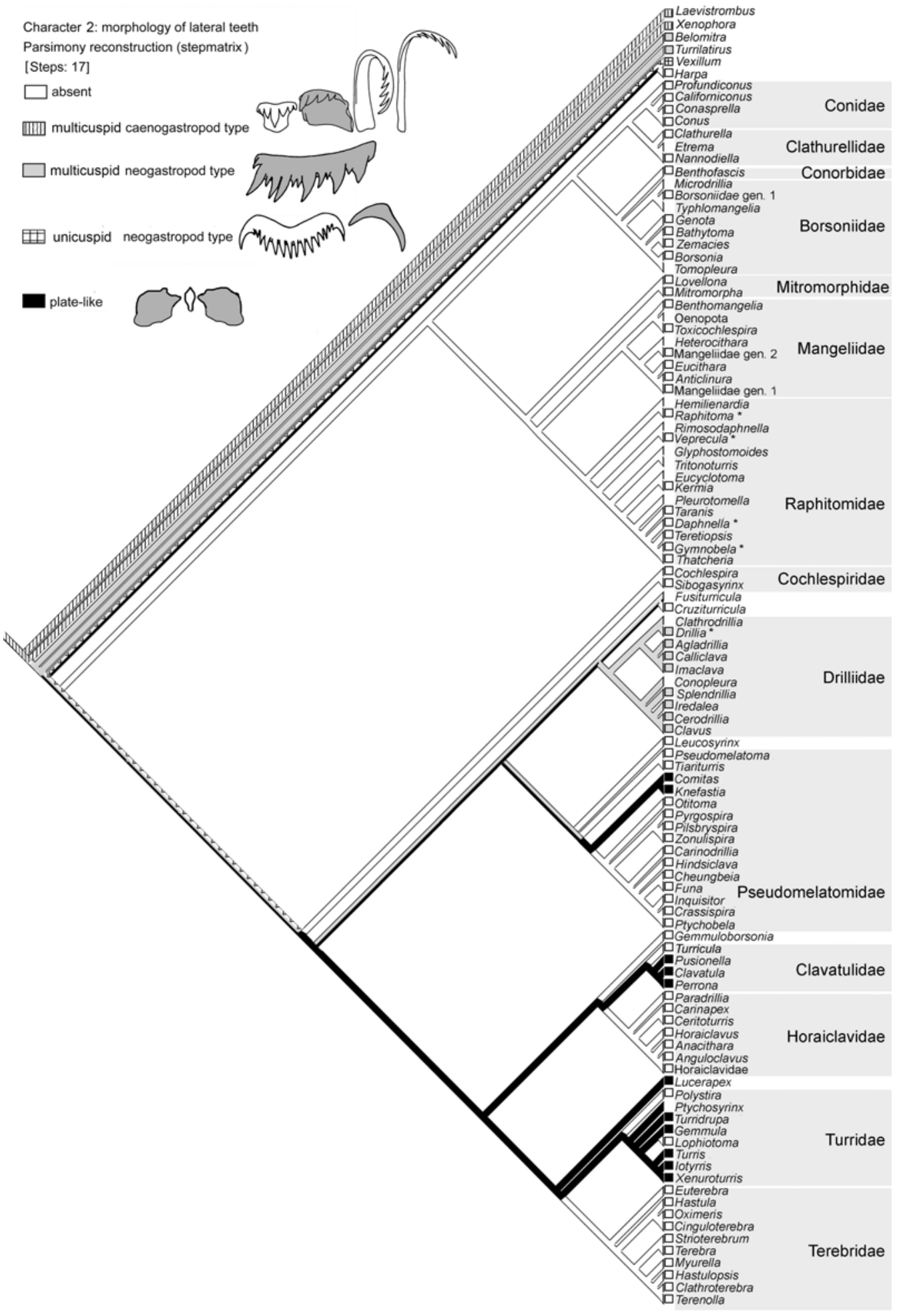

Fig 27 

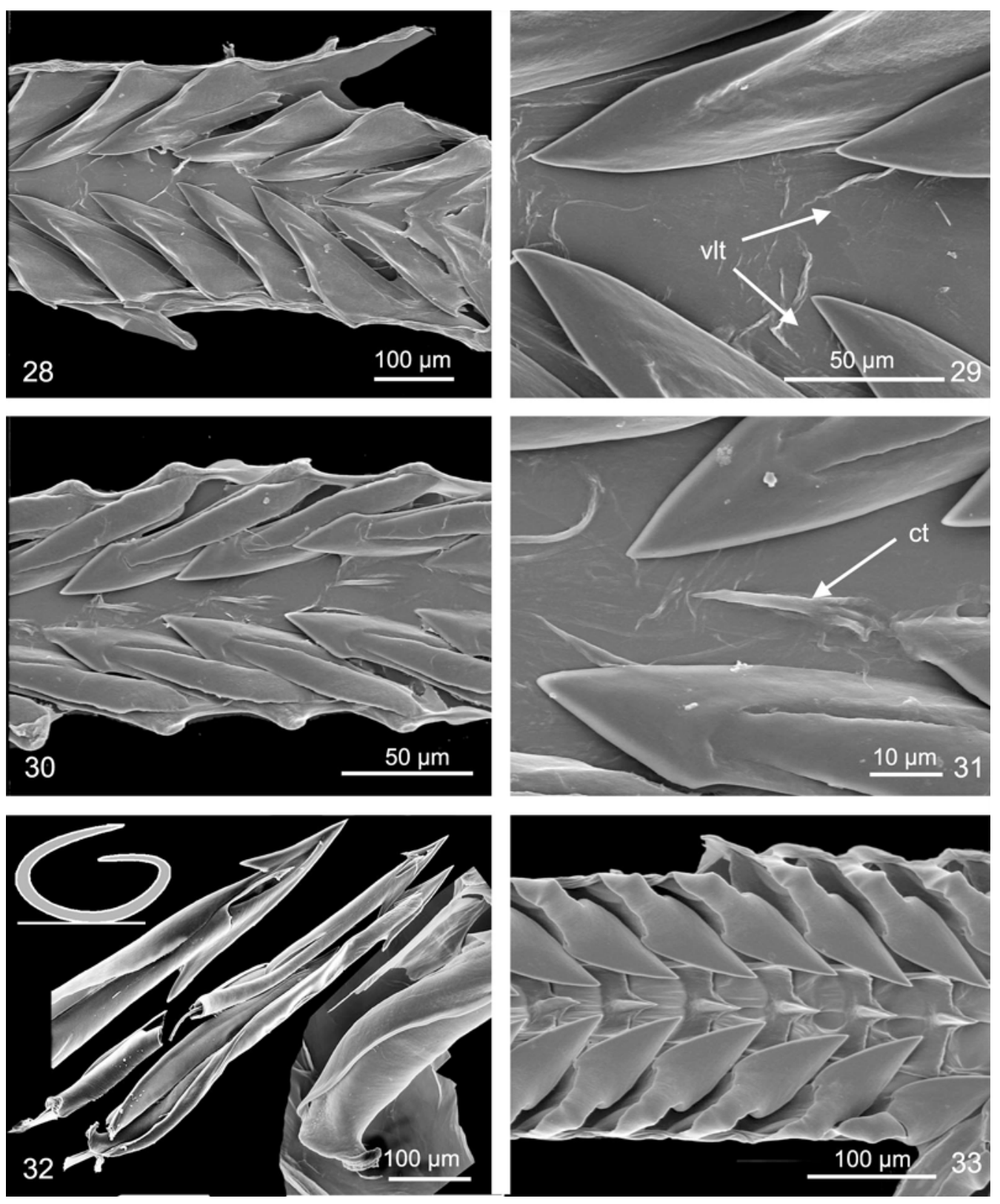

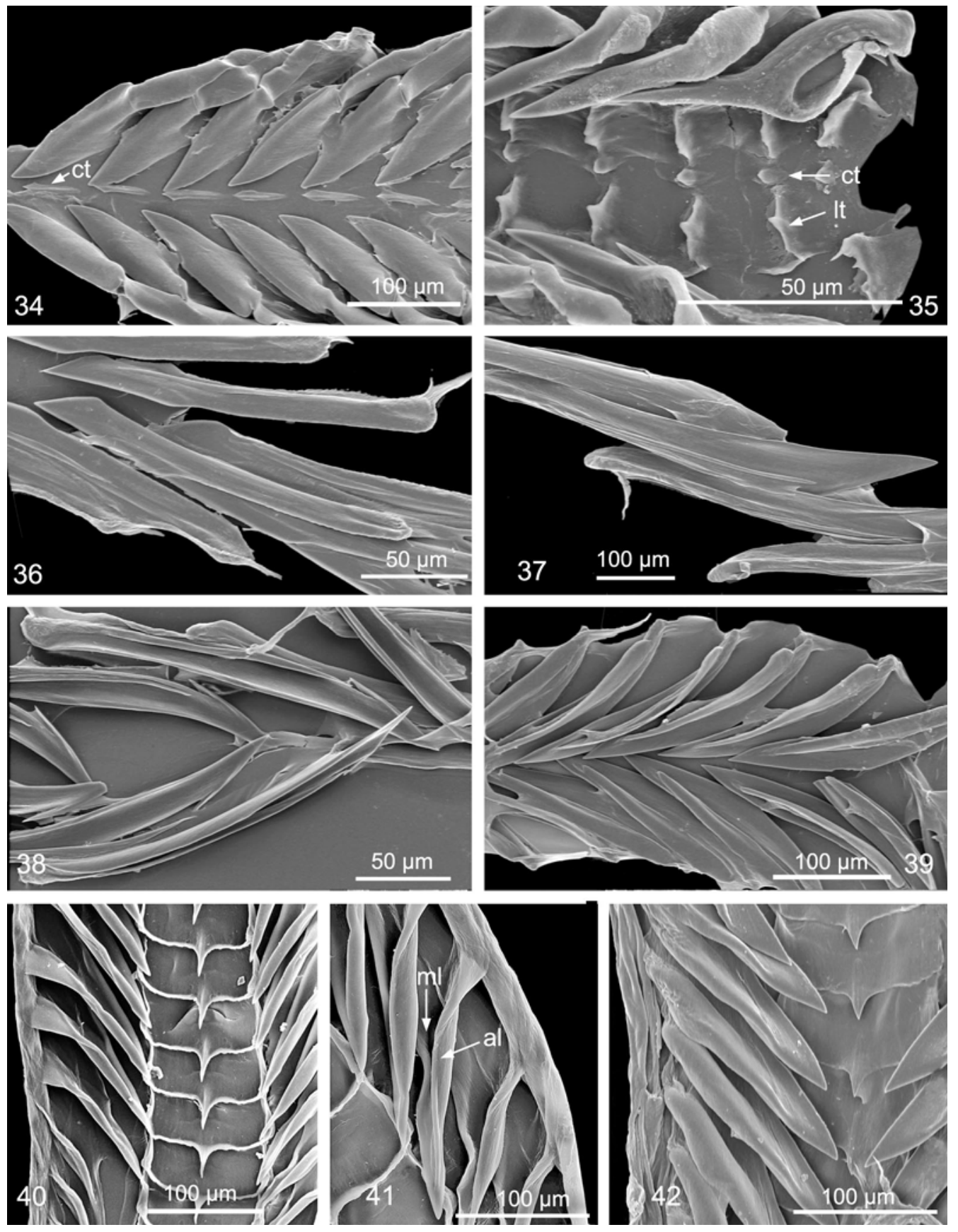


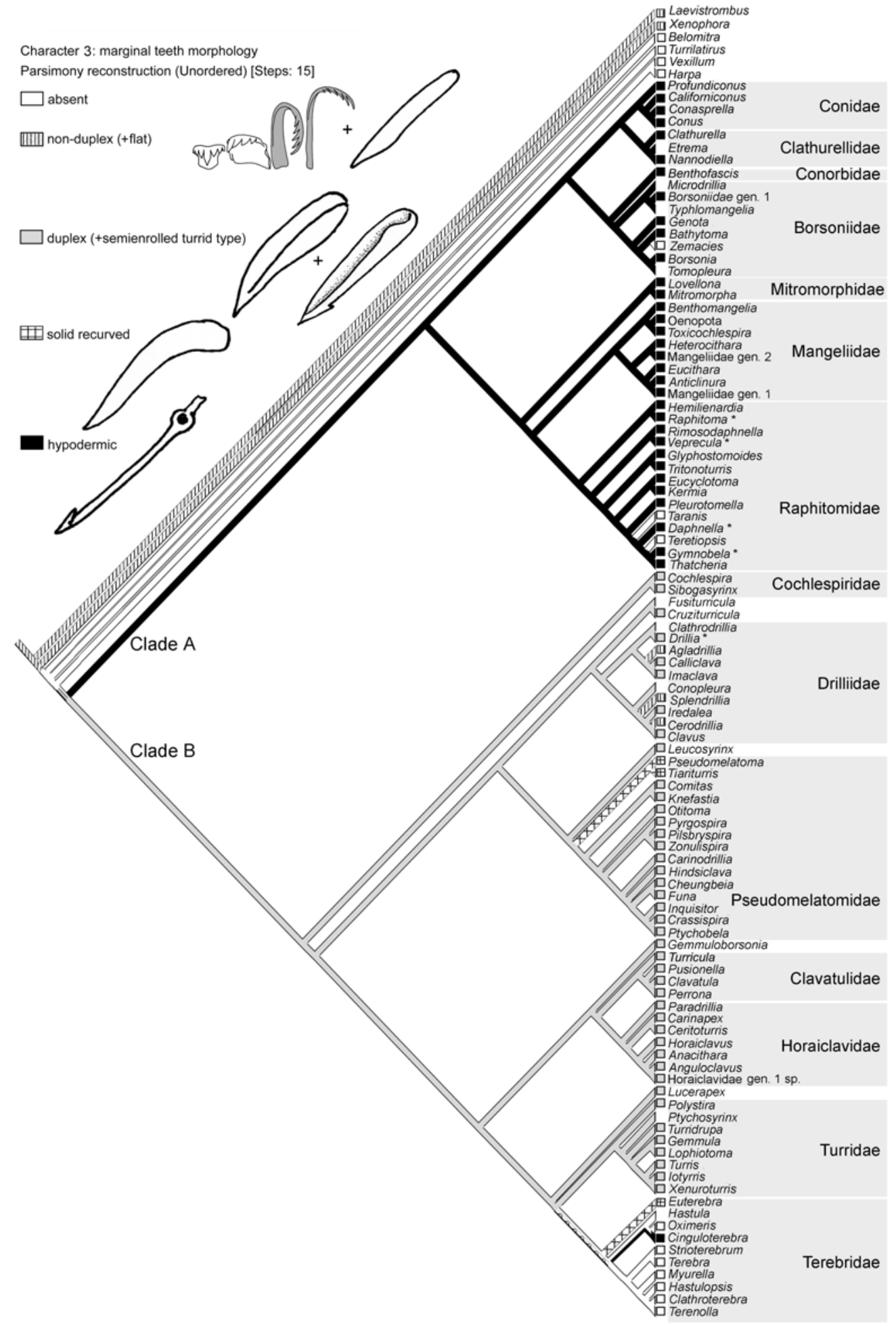

Fig 43 


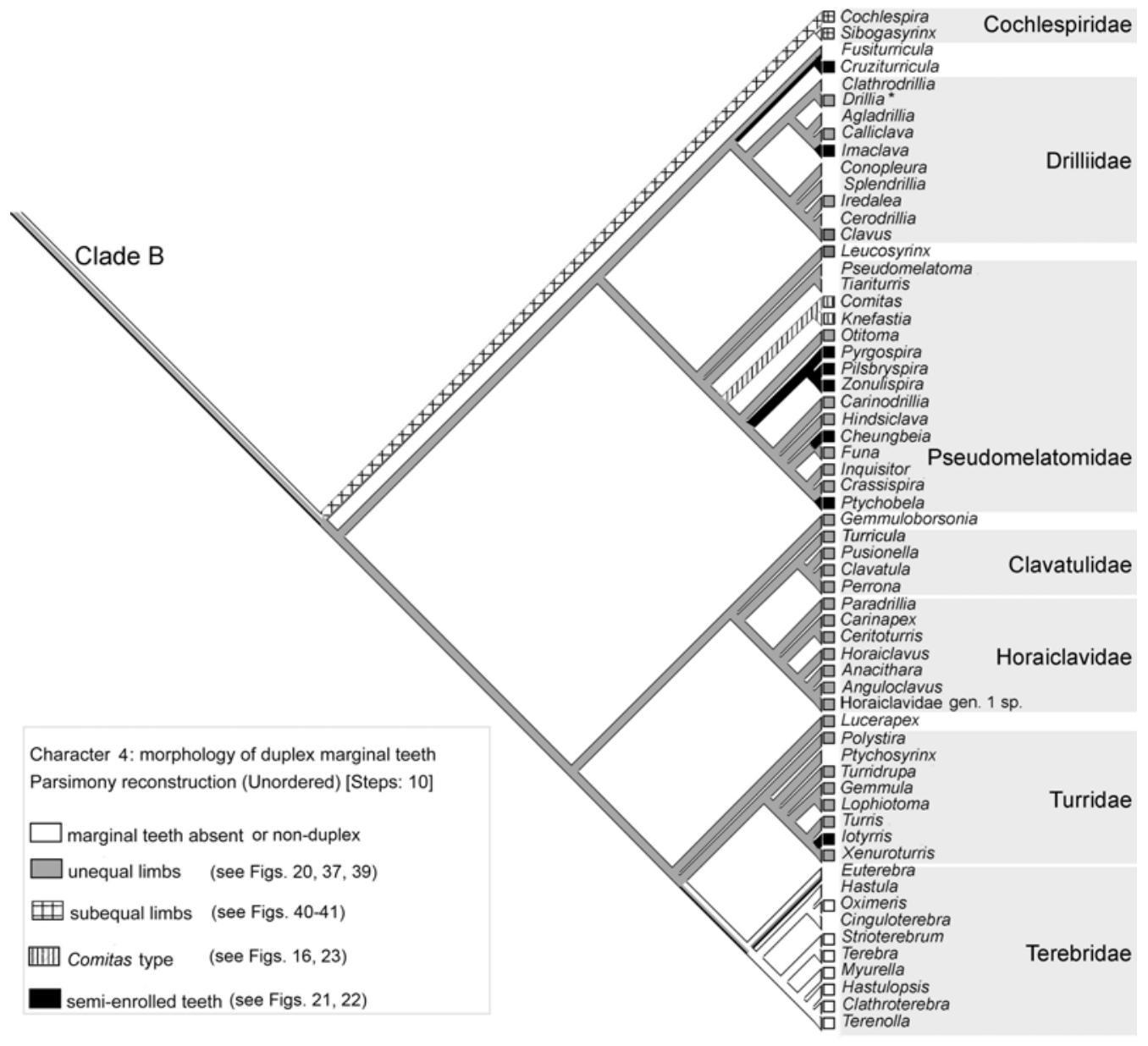




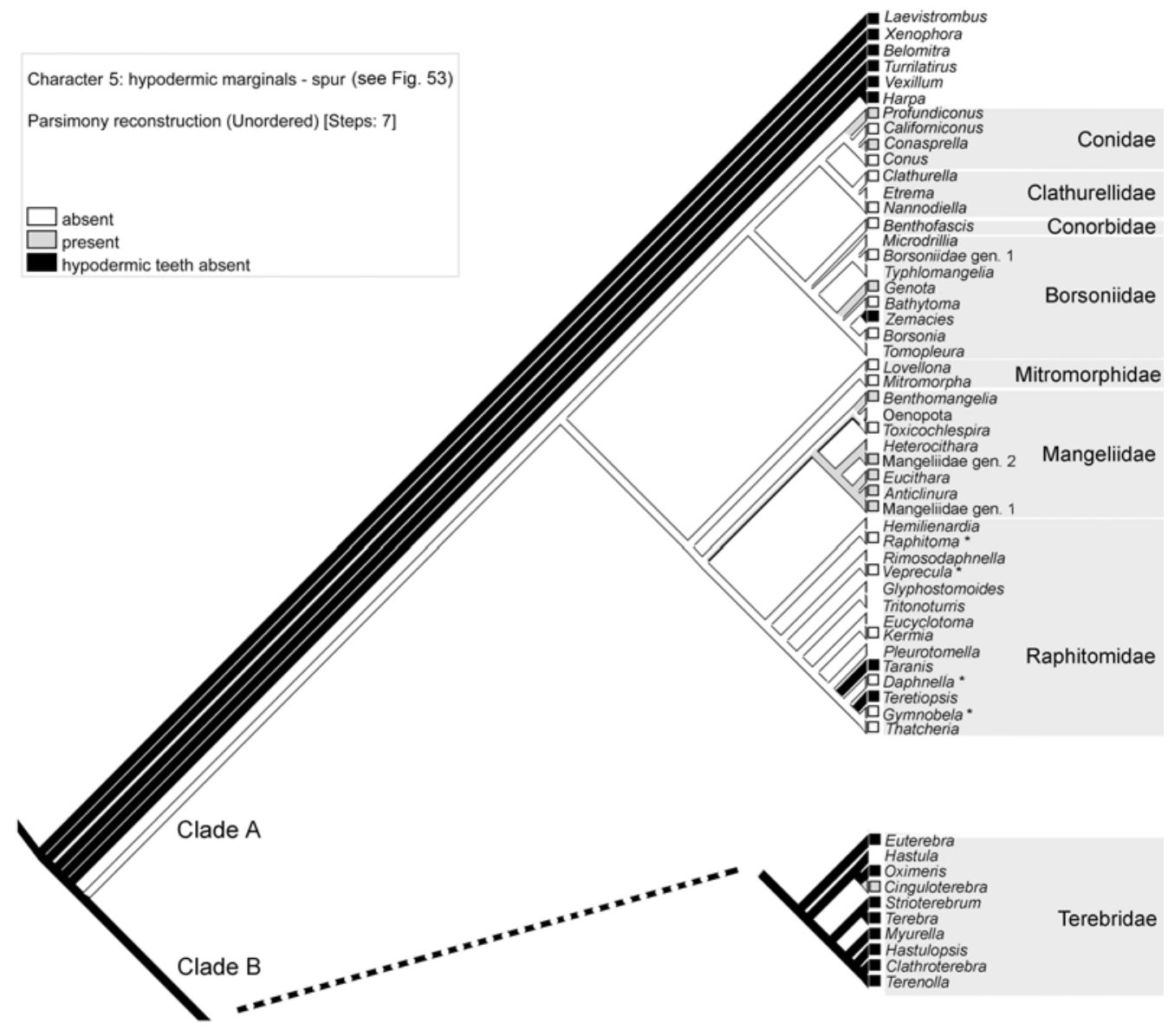

Fig 45 

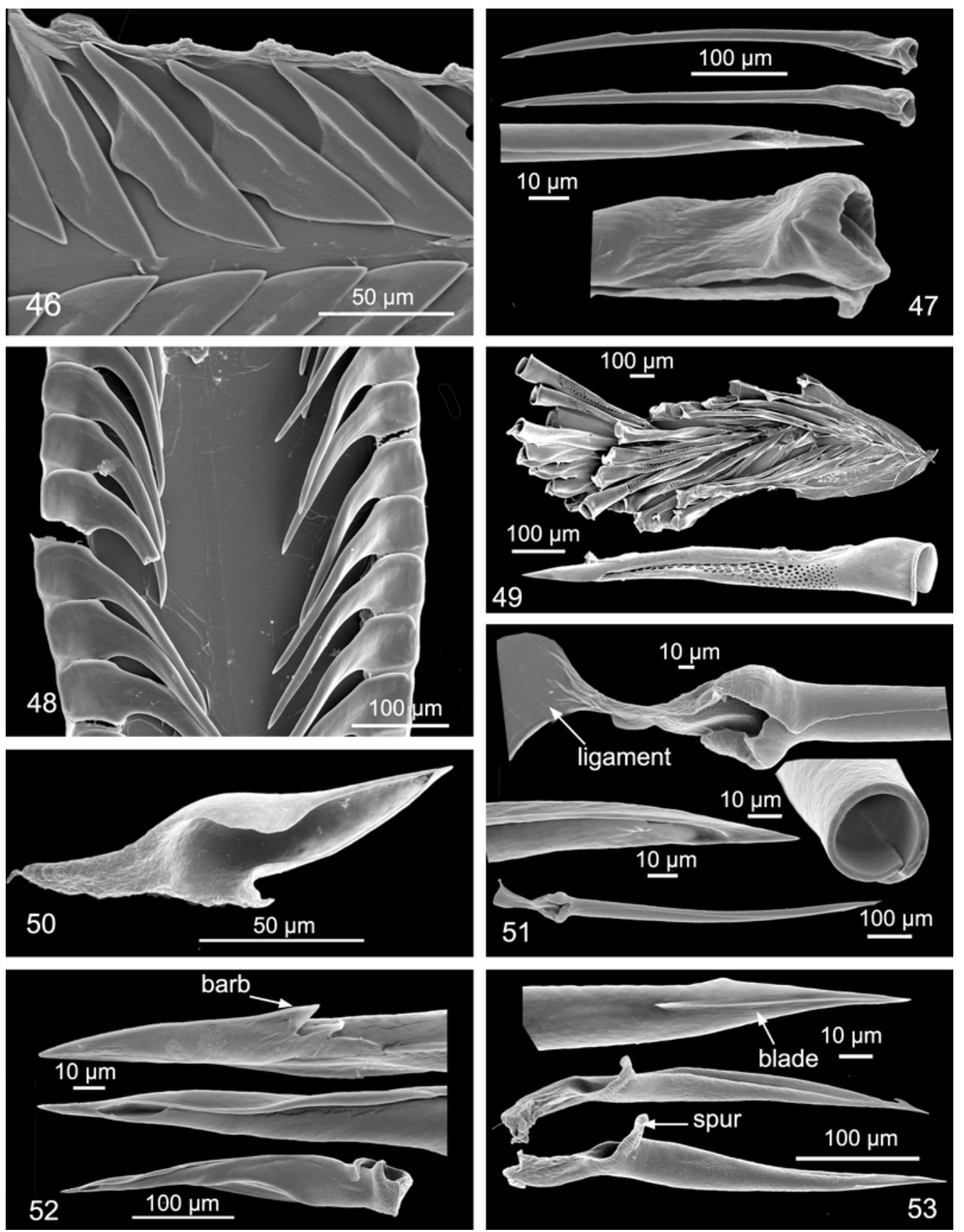


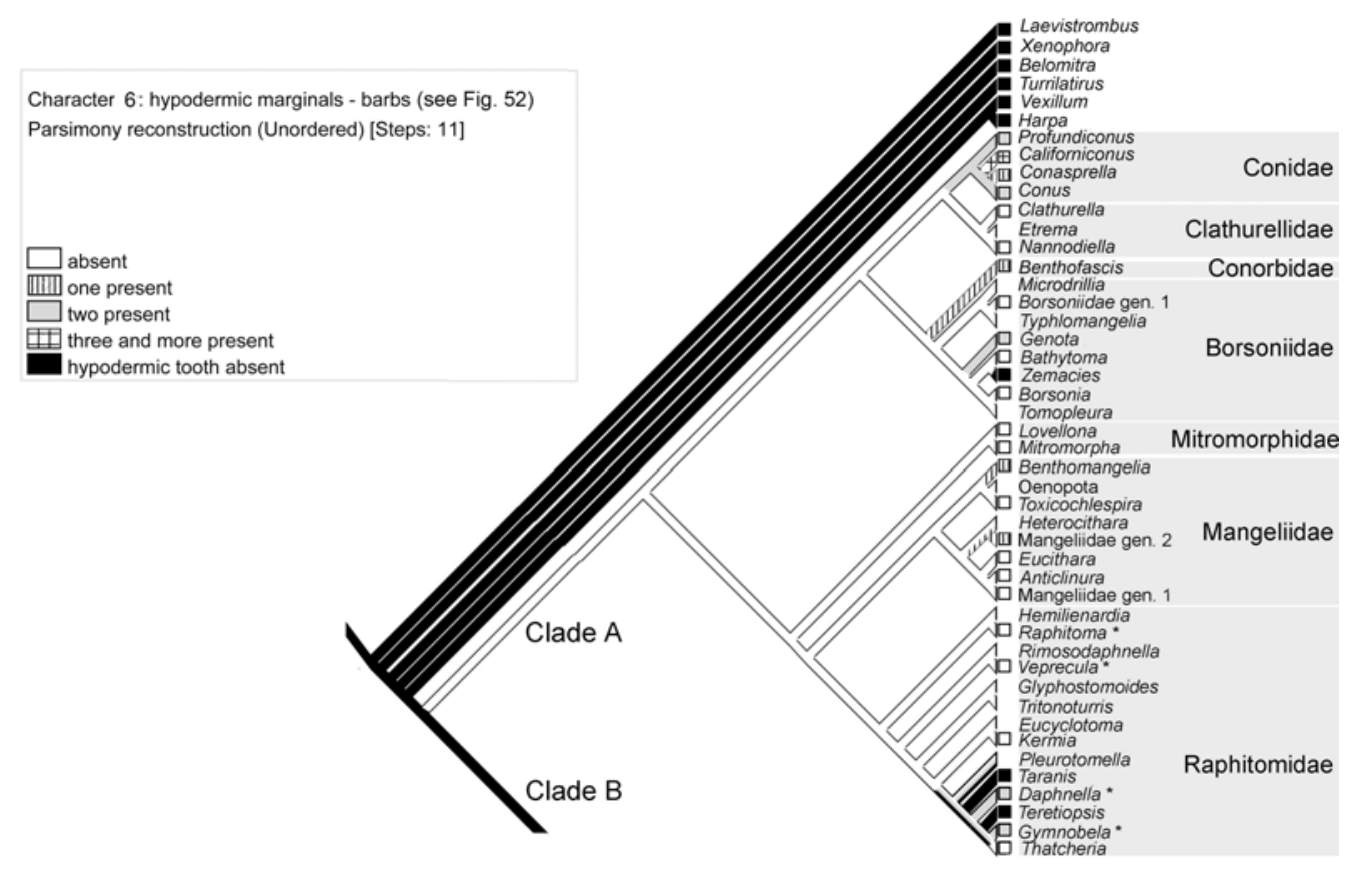

Fig 54 


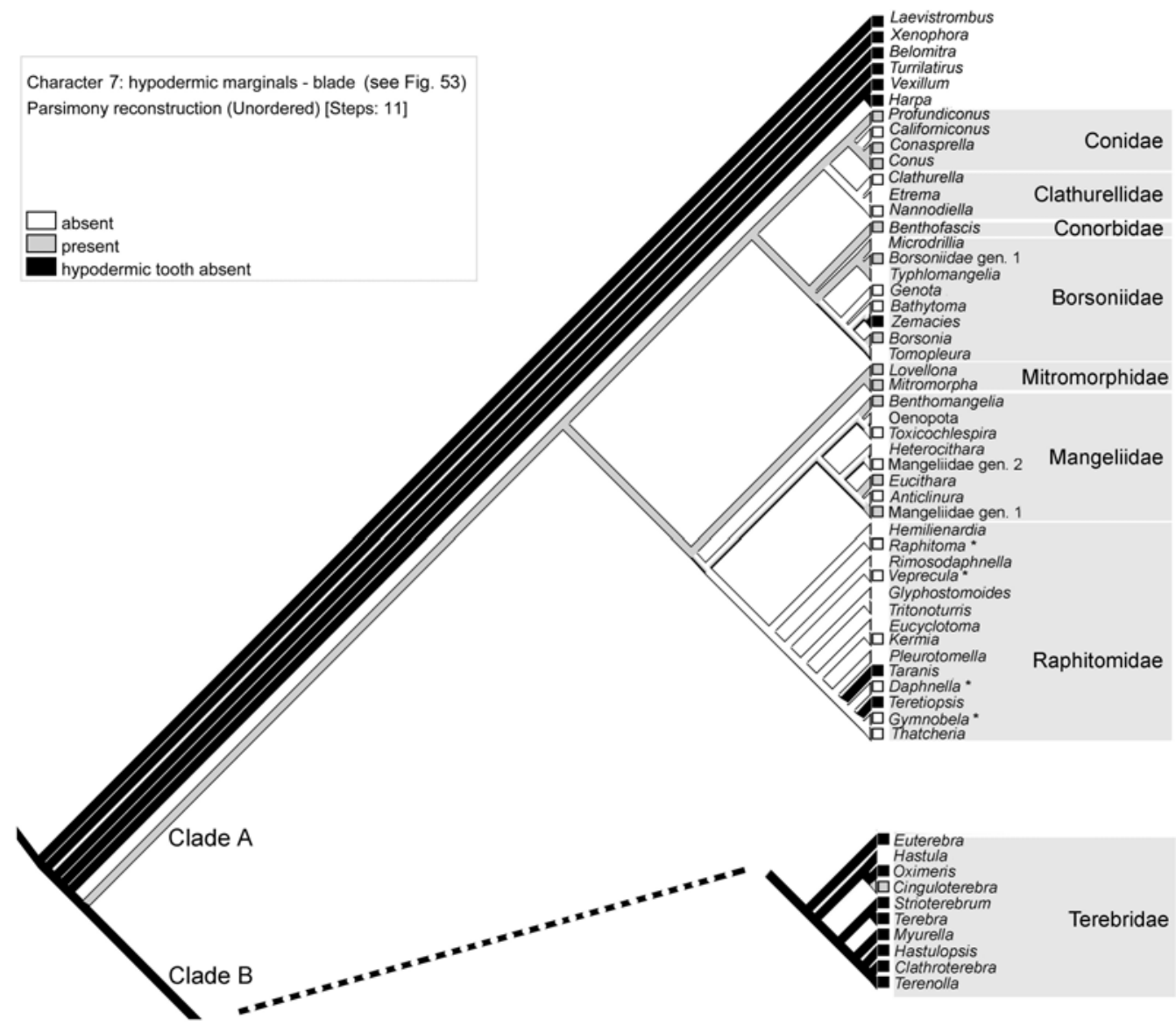




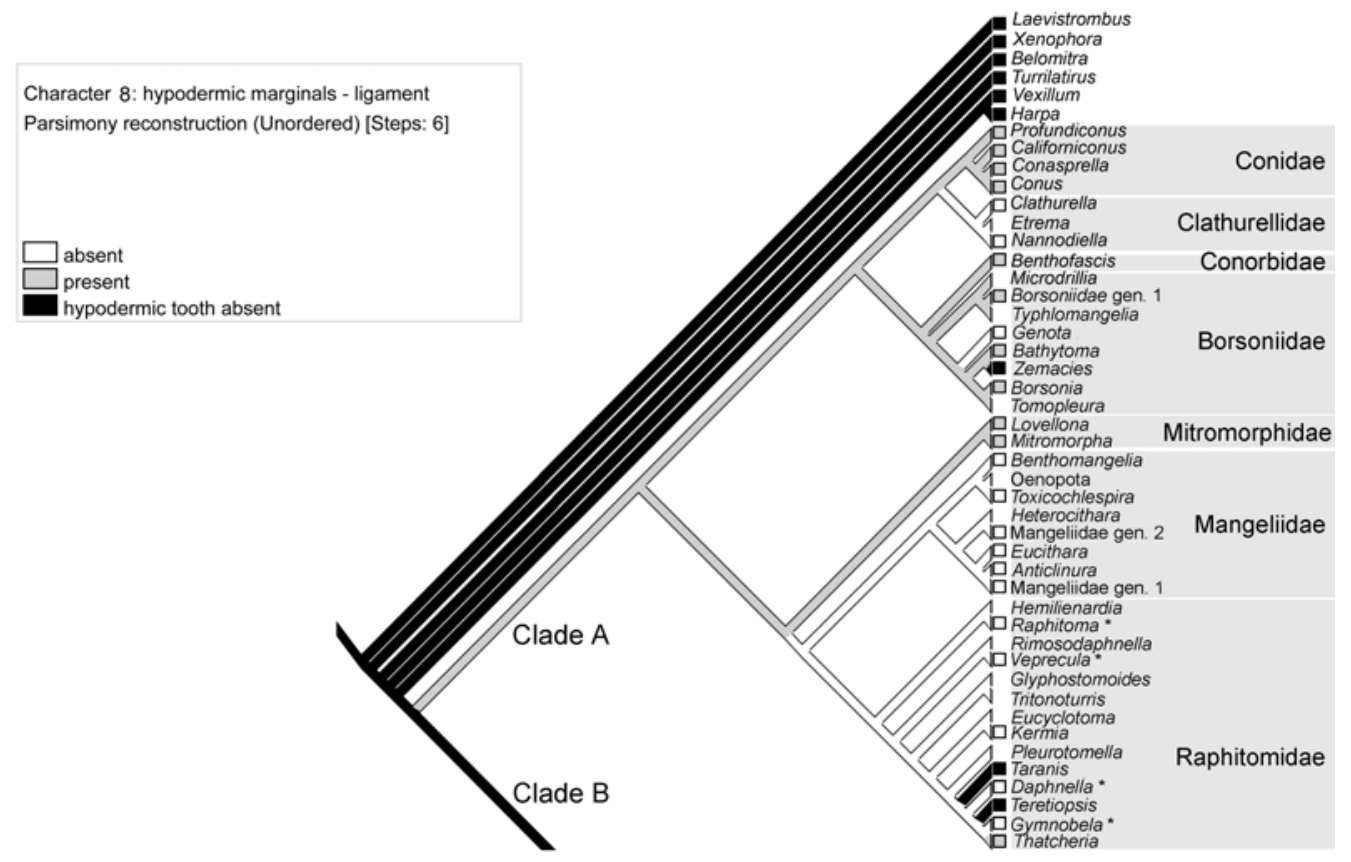

Fig 56 


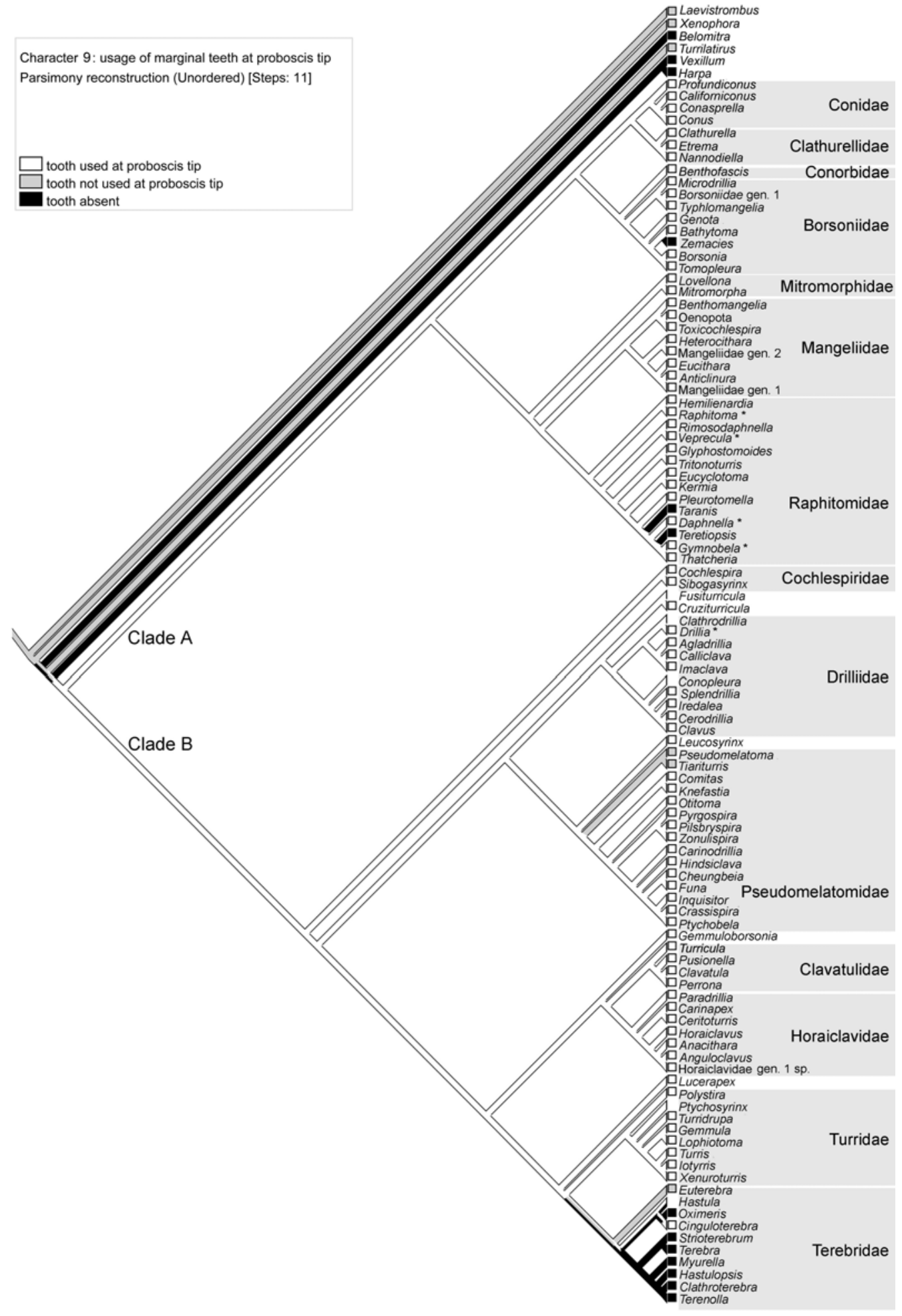



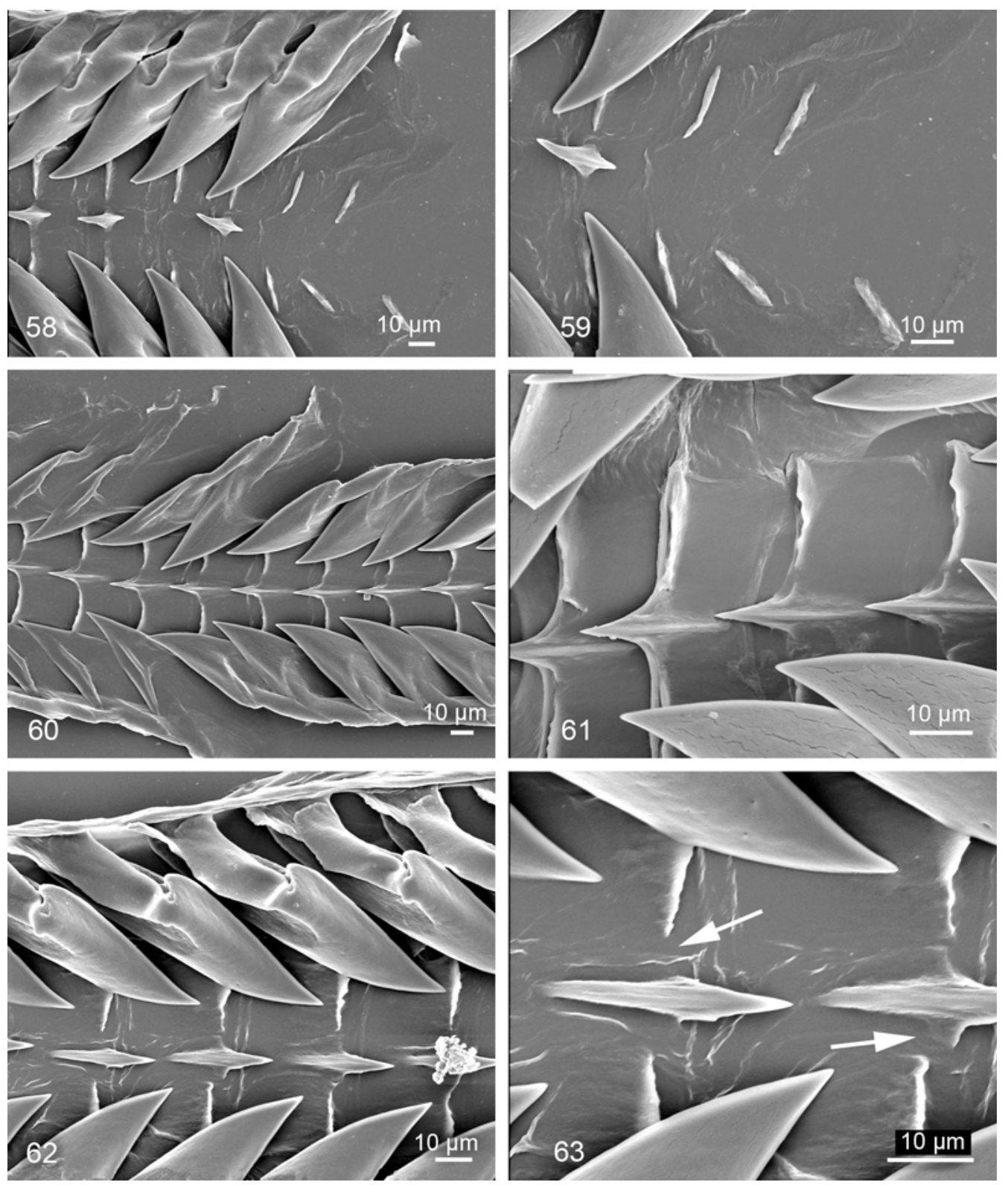